\title{
Kamu Diplomasisinde Dijital Dönüşüm: Büyükelçilerin Twitter Üzerinden Gerçekleştirdikleri Dijital Diplomasi Faaliyetlerinin İncelenmesi
}

Mesut İRIS, Istanbul University, Journalism Department, Res. Assist., mesutiris@istanbul.edu.tr, 0000-0003-1640-6446

Tansu AKDEMIR, Istanbul University, Journalism Department, Res. Assist., tansu.akdemir@istanbul.edu.tr, (iD) 0000-0002-5150-3340

$\ddot{O Z Z}$

İletişim teknolojilerinin gelişimi, kişilerarası ilişkileri etkilediği gibi devletler ve toplumlar ile olan ilişkileri de yeniden düzenlemektedir. Devletler sadece ilgili devletler ile diplomatik faaliyetler içerisinde bulunmamış, aynı zamanda etki alanı inşaa ettiği her alanda toplumları ikna etme ve stratejik hedefleri doğrultusunda bakış açısı üretme çabasına girmiştir. Kamu diplomasisi olarak da adlandırılan kamuoyuna yönelik faaliyetler iletişim teknolojilerinin gelişimiyle birlikte yeni mecralarda farklı kurallar ile devam etmektedir. Günümüz dijitalleşen dünyasında devletler ve devletlerin tüm bürokrasisi dijitalleşmeye ayak uydurarak kendi toplumuna anlik olarak ulaşabilir ve geri bildirim alabilirken, farkl toplumlara da ulaşabilmekte ve anlık olarak stratejik politikalar üretip sonuç alabilmektedir. Bu çalışmada kamu diplomasisin bir dalı olarak dijital diplomasinin Türkiye özelinde kullanımı incelenmiştir. Çalışma ile Türkiye'nin gerçekleştirdiği askeri operasyonlarm uluslararası ortamda yankılarmın ve diğer toplumlar nezdinde kamuoyuna yönelik gerçekleştirilen dijital diplomasi faaliyetlerinin görülebilmesi amaçlanmaktadır. Bu amaçla Barış Pınarı Harekâtı sırasında büyükelçilerin Harekâtı n uluslararası camiadaki haklhlığı ve gerekliliğine ilişkin yürüttü̈kleri dijital ve kamu diplomasisi faaliyetleri seçilen sosyal medya örneklemi üzerinden incelenecek, dijital çă̆a ne kadar uyum sağlandığ ve dijital temelli iletişim kanallarından ne kadar yararlanıldı̆̆̆ da görülecektir.

Anahtar : $\quad$ Twiplomacy, Kamu Diplomasisi, Dijital Diplomasi, Barış Pınarı Harekâtı

Kelimeler

\section{Digital Transformation in Public Diplomacy: Examining the Digital Diplomacy Activities of Ambassadors via Twitter}

The development of communication technologies affects interpersonal relationships, as well as reorganizing relationships with states and societies. States have not only engaged in diplomatic activities with the relevant states, but have also sought to convince societies in all areas in which they have built a sphere of influence and to create a point of view in accordance with their strategic goals. Public activities, also called public diplomacy, continue with different rules in New Media with the development of communication technologies. In today's digitized world, States and the entire bureaucracy of states can instantly reach and receive feedback to their own society by keeping up with digitization, while they can also reach different societies and instantly produce strategic policies and get results. In this study, the use of 
digital diplomacy as a branch of Public Diplomacy in Turkey was examined. The aim of the study is to see the repercussions of Turkey's military operations in the international environment and the digital diplomacy activities carried out for the public in other societies. For this purpose, during Operation Peace Spring, the ambassadors the operation in the international community regarding the legitimacy and necessity of social media and the digital public diplomacy activities carried out on the sample selected to be examined, adopted what the digital age and digital-based communication channels will make use of.

Keywords : : Twiplomacy, Public Diplomacy, Digital Diplomacy, Operation Peace Spring

\section{GíRiş}

Yumuşak güç olarak da tanımlanabilecek olan kamu diplomasisi, devletlerin birbirleri ile olan ilişkilerinde kullandıkları ve diğer ülke vatandaşlarına yönelik gerçekleştirdikleri iletişim faaliyetleridir. Bu iletişim faaliyetleriyle hedeflenen, uluslararası çapta etki alanı oluşturmak, ikna etmek ve bakış açısı değiştirmektir. Kamu diplomasisi doğal paydaş olduğu iletişim araçlarıyla da şekillenmektedir. Değişen ve gelişen iletişim teknolojileri kamu diplomasisi faaliyetlerini de etkilemiştir. Mecralar değişmiş, etki alanı artmış, karşılıklı etkileşim oranı yükselmiş ve anındalık önemli bir unsur haline gelmiştir. Diplomatik faaliyetler açısından oldukça önemli bir noktada duran kamu diplomasisi dijital ortamlarda yürütülmeye başlanarak, başta devletlerin dış ilişkiler kanadında olmak üzere uluslararası platformlarda yer almıştır.

Kitlelerin yer aldığı dijital mecralar, dijital diplomasi kavramının doğmasına yol açmıştır. Milyonlarca insanın her an paylaşım gerçekleştirdiği ve geri bildirimde bulunduğu dijital platformlar ve sosyal medya uygulamaları diplomasinin de dijitalleşmesine neden olmuştur. Artık toplumun tüm temsiliyetinin yer aldığ 1 kamusal alan dijitalleşirken, devletlerin diplomasi faaliyetlerinin olmazsa olmaz stratejileri dijital mecraları da içermektedir.

Çalışma, kamu diplomasisi faaliyetlerinin dijital dönüşümünün ve dijital diplomasi faaliyetlerinin ne ölçüde gerçekleştirildiğinin görülmesini amaçlamaktadır. Bu amaç doğrultusunda öncelikle altyapı oluşturacak literatür taraması yapılarak dijital diplomasiye yönelik yaklaşımlar değerlendirilecektir. Dijital diplomasi faaliyetlerinin pratikte görülebilmesi ve değerlendirilebilmesi amacıyla da Barış Pınarı Harekâtı sırasında büyükelçilerin, Harekâtı n uluslararası camiadaki haklılığı ve gerekliliğine ilişkin yürüttükleri dijital ve kamu diplomasisi faaliyetleri seçilen sosyal medya örneklemi üzerinden incelenecektir. Güncel operasyonları tamamlayıcı iletişim faaliyetlerin görülmesi, varsa eksik yanlarının iyileştirilmesi ve çağın gereklilikleriyle uyumlu hareket edilebilmesi açısından çalışmanın sonuçları önem arz etmektedir. 


\section{Diplomaside Dijital Dönüşüm}

Günümüz toplumunda artık tek taraflı enformasyon devri yerini çoklu enformasyon devrine bırakmıştır. 18. ve 19. yüzyılların teknolojik gelişmelerinin sonucu olan sanayi toplumu bilişim teknolojisindeki gelişmeler ile 20. ve 21. yüzyılda ağ toplumuna dönüşmüştür. Jan van Dijk'in A ̆̆ Çağı olarak tanımladığı 21. yüzyılda ağlar toplumların sinir sistemini oluşturmaktadır ve bu ağlar günümüzde mal taşımacılığı yapılan karayollarından çok daha etkili olarak bilgi karayollarını oluşturacaklardır (Dijk,1992). Geleneksel düzende yukarıdan aşağıya doğru ya da kaynaktan kitleye doğru gerçekleşen enformasyon akışına günümüzde bireyler de dahil olmuş, söz konusu enformasyon akışına aşağıdan yukarı doğru veya hemen her yönden enformasyon akışı eklenmiştir. Enformasyon akış düzeninin değişmesine ek olarak, sosyal medya uygulamaları ve dijitalleşmenin geldiği nokta itibariyle anındalık elde edilmiştir. Toplumun sadece gözüken üyelerinin taleplerinin, isteklerinin veya şikayetlerinin yanı sıra azınlıkta kalmış üyelerinin de sesleri dijitalleşmeyle birlikte duyulur hale gelmiştir. Nitekim dijital aktivizm doğmuş, toplumlar sadece kendi coğrafyalarındaki sorunlarla ilgilenmekle kalmamış, dünyanın herhangi bir yerinde gerçekleşen anlık olaylara tepki verebilir ve görüşlerini paylaşabilir hale gelmiştir.

İlk kez 1963 yılında ABD Bilgi Servisi (USIA - United States Information Agency) müdürü Edward Murrow tarafından kullanılan kamu diplomasisi kavramı (İnan, 2012) hükümetlerin, geleneksel olarak hükümetler ile kurdukları ilişkileri düzenleyen bir alan olmanın dişında kamuya ait olan tüm kesimlerle iletişim faaliyetlerine girilmesi olarak tanımlanmaktadır.

Stratejik iletişim ve yumuşak güç gibi kavramların kullanıldığı kamu diplomasisinde, halkların düşüncelerine ve duygularına erişme, onlara etki edebilme ve onları kazanabilme faaliyetleri söz konusu olmaktadır (Yücel, 2016).

Hükümetler, diğer uluslara yönelik stratejilerinde geleneksel yöntemlerin dışarısına çıkarak yeni yollar denemeye başladılar. Sinema, turizm, kültür - sanat ve eğitim gibi stratejik alanlarda halkların duygularına yön verici içerik ve faaliyetlere yer verilerek rızaları kazanilmaktadır.

Dijitalleşmeyle birlikte kamuya ait olan tüm dinamikler internet yoluyla birbiriyle entegre olmuştur. Toplum dijitalleşirken, topluma en hızlı şekilde ulaşabilme, nüfuz edebilme yolu hükümetlerin de dijitalleşmesi olmuştur. Nitekim dijital diplomasi kavramı da hükümetlerin strateji ve hedefleri doğrultusunda uluslara ulaşabilecekleri dijital ortam arayışı üzerine doğmuştur. Hükümetlerin stratejileri doğrultusunda hedeflerinin başarıya ulaşmasında internet ve dijital teknolojilerin kullanılması dijital diplomasi olarak tarif edilmektedir (Saka ve Ezgin, 2016). Manuel Castells'in bilgi teknolojilerine dayandırdığı ve bilgiyi merkeze oturtan enformasyonalizm kuramı, dijital diplomasi kavramına bir arka plan sunmaktadır. Bilişim teknolojileri ile birlikte bilgi temelli bir toplum oluşmuş dahası bireyler bilgi üretiminin mihenk taşı olmuşlardır. Bireyler arası bilgi akışı böylece kesintisiz ve aralıksız sürer hale gelmiş, ağlar üzerinden işleyen interaktif bir toplumsal yapı oluşmuştur. Kurama göre 
bireylerin ağlar üzerinden bir araya gelmesi yanında siyaset ve diplomasi de ağlar üzerinden yürütülecektir (Ekşi, 2016).

Nitekim, dijitalleşmenin sonuçlarıyla karşılaşan devletler, yumuşak güçlerinin sınırlarını ve etki alanlarını geliştirmek üzere yeni yollar denemeye başlamışlardır. Sosyal medyayı kendi lehlerine kullanarak siyasi liderlerini halkları etkilemek amacıyla markalaştırmışlardır (Uysal ve Schroeder, 2019). Buna örnek olarak Amerika Birleşik Devletleri Başkanı Donald Trump'ın ve Rusya Devlet Başkanı Putin'in stratejik olarak güçlü bir lider imajı yansıtmak için sosyal medyayı kullanmaları verilebilir. Liderlerin yüceltilmesi ve kahramanlaştırılarak mükemmel, hata yapmaz figürler olarak görülmeleri olarak tanımlananan kişilik kültü kuramı, Max Weber' in Karizmatik Otorite fikrine dayanmaktadır (Cassiday ve Johnson, 2010). Bu noktada sosyal medya multimedya doğası, sunduğu kolay erişim ve geniş çapta etkisi ile siyasi liderlerin, kamusal söylemdeki faaliyetlerini yayarak, kişisel markalarını yükseltmelerini, sosyal ve iletişimsel ilişkilere dayanan yeni bir kişilik kültü yaratmaları yoluyla kolaylaştırmıştır.

\section{Kuralları Yıkan Diplomasi; Twiplomacy}

Kamu diplomasisinin yöntem, kural, aktör, süreç ve araçlarını değiştirmiş olduğunu söyleyebileceğimiz dijital diplomasinin kendi içerisinde yeni bir yapılanma inşa ettiği görülmektedir. Sosyal medyanın etkisi ile kullanıcılar aracıları aradan çıkartıp kendi başlarına yeni iletişim kanalları geliştirmekte, bürokrasinin ağır işleyişinin aksine 7 gün 24 saat açı ve etkileşim halinde olan dijital medya kanalları ile bireyler düşünce, istek ve beklentileri ile her an bu geniş etkileşim ağının içine dahil olabilmektedirler. Bu dönüşüm sonucunda sosyal medyanın kamu diplomasisi için birincil bir kanal haline geldiğini söylemek mümkün olmaktadır. Her an erişim imkanı ve çok yönlü iletişimi ile sosyal medya, ağ üzerinden birbirine bağlı yabancı halkların birbirine erişimini sağlayarak katılım yoluyla demokrasinin geliştirilmesi potansiyeline de sahiptir.

Son y1llarda gelişen bir kavram olarak 'Twitter diplomasisi' veya 'Twiplomacy' ile, devlet başkanları, hükümetler arası kuruluşların liderleri ve diplomatlar Twitter'ı diplomatik ve kamu diplomasisi amaçlı kullanmaktadır (Su \& Xu, 2015). Twiplomacy ile kamu diplomasisi faaliyetlerinin dijital ortamlarda gerçekleştirilmesi söz konusudur. Twitter liderleri ve diplomatları kamu diplomasisini yeniden düşünmeye ve tasarlamaya itmiştir. Günümüzde devlet başkanları ve hükümet yetkililerinin çoğunun Twitter hesabının bulunduğu görülmektedir. Diplomasinin Twitter gibi sosyal ağlar aracılığıla yürütülmesi, halkların diplomasinin aktörleri arasında gelişen iletişimi 'retweet'ler, mention'lar ve cevaplar' üzerinden görebilmesi ve takip edebilmesine olanak tanımıştır.

20 Ocak 2017 tarihinde ABD Başkanlık koltuğunu Barack Obama'dan devralan Donald Trump, seçilmeden önceki davranışlarıyla aslında nasıl bir başkan olacağının sinyallerini vermiştir. Seçim kampanyası döneminde ortaya koyduğu strateji, sloganvari konuşmaları ve sosyal medya kullanımı ile dünyanın ilgisini çekmeyi başarmıştır. 
İç ve dış politikaya yönelik stratejik hamlelerini özellikle Twitter üzerinden açılamaktan çekinmeyen Trump, kapalı kapılar ardında sürdürülen diplomasi faaliyetlerini yıkmıştır. Başkanlığının ilk yılında Kuzey Kore ile olan ilişkileri neredeyse savaşa kesin gözle bakılan bir duruma sokmuş, Twitter üzerinden Kuzey Kore lideri Kim Jong-un'a yönelik çok sert söylemlerde bulunmuştur. Kuzey Kore liderine "Rocket Man” yani roket adam lakabını takan Trump, "Roket Adama iyi davranmak 25 yıldır işe yaramadı, neden şimdi işe yarasın?", "Benim Nükleer düğmem onunkisinden daha büyük ve daha güçlü ve düğmem çalışıyor" (Twitter, 2018) gibi ilişkileri neredeyse savaşa götürecek kadar sert açıklamalar yapmaktan çekinmemiştir. "Zorunda kalırsak Kuzey Kore'yi yok ederiz." cümlesini kuran Trump, tüm dünyanın gözünü Twitter yoluyla kendisine çekmeyi başarmıştır. Tüm dünya savaşın an meselesi olduğunu ve Trump'ın yeni öngörülemez hareketinin ne olacağını beklerken, o ise Kim Jong-un ile buluşmuş, hatta Kuzey Kore'ye ayak basan ilk ABD Başkanı olmuştur. Trump, dijital diplomasi ile önce tüm dünyayı onu izlemeye yönlendirmiş, gerilimi tırmandırmış ve tam tersi bir hareketle tüm sorunu çözen bir davranışta bulunmuştur.

Barış Pınarı Harekâtı sürecine bakıldığı zaman, Trump başta olmak üzere uluslararası mecrada harekat karşıtı bir çok paylaşımda bulunulmuştur. Nitekim Donald Trump, Barış Pınarı Harekâtı ile Türkiye'nin Suriye topraklarını işgal ettiğini Twitter üzerinden açıklamıştır. Trump, Türkiye'ye yönelik tweetlerinde bölgede bulunan terörist unsurlarla anlaşılması gerektiğini belirtmiştir. Türkiye tarafında ise Harekâtı $n$ haklı gerekliliğini ortaya koyan açıklamalarda bulunulmuştur. Ancak uluslararası ortamda bir çok aktör üzerinden harekât karşıtı dijital diplomasi faaliyetleri yürütülmesi, Türk dış politikasının özellikle dijital diplomasi faaliyetlerine yoğunlaşması gerektiğini ortaya koymuştur.

Günümüzde uluslararası toplum ve kamuoyunun desteği haklı durumlarda dahi gereklidir. Ülkelerin uluslararası camiada hukuken haklı olması dahi bu durumu değiştirmemektedir. “Bilişim teknolojileri, siyasal iletişimin araç ve mekanizmalarını değiştirdiği için, geleneksel diplomatik yöntem ve araçlarla uluslararası toplumu ve kamuoyunu ikna etmek neredeyse imkânsız hale gelmiştir"' (Ekşi,2016).

\section{Yöntem}

Çalışma ile kamu diplomasisi faaliyetlerinde dijital diplomasi kullanımının görülmesi amaçlanmaktadır. Yurt dişında bulunan temsilcilik faaliyetlerinde dijital diplomasi kullanımlarının incelenmesi, Barış Pınarı Harekâtı özelinde gerçekleştirilen dijital diplomasi faaliyetlerinin görülmesi ve Barış Pınarı Harekâtı özelinde gerçekleştirilen dijital diplomasi faaliyetlerinin ortak bir strateji doğrultusunda gerçekleştirilip, gerçekleştirilmediğinin incelenmesi çalışmanın önem arz eden amaçlarındandır.

Çalışmanın örneklemini Avrupa Birliği nezdinde iki başat ülke olan Fransa ve Almanya oluşturmaktadır. Gerek mülteci sorunu, gerek Orta Doğu politikalarında Türkiye'nin karşısında konumlanan ve Avrupa Birliği'nin en aktif siyaset güden iki ana ülkesi konumunda olan Fransa ve Almanya'ya yönelik gerçekleştirilen dijital diplomasi faaliyetlerinin önemi, örneklem seçiminde neden bu iki ülkenin seçildiğini açıklamaktadır. Çalışmanın kapsamını 
bu ülkelerde yer alan Büyükelçiler ve Büyükelçilik twitter hesapları oluşturmaktadır. Çalışmanın sınırlılıklarını ise, twitter hesaplarından Harekâtı n başladığı 09 Ekim 2019 tarihi ve 14 Kasım 2019 tarihi arasında yapılan harekât ile ilgili paylaşımlar oluşturmaktadır.

Çalışmada yöntem olarak içerik analizi kullanılmıştır. İçerik analizi yöntemi nicel ve nitel analizlerin yorumlanmasıyla oluşmaktadır. Harold Laswell' in iletişim üzerine gerçekleştirdiği çalışmalar ile elde etmiş olduğu "kim, ne diyor, hangi kanalı kullanıyor, kime, ne gibi bir etki ile?" formulü içerik analizinin de yapısını şekillendirmiştir (Yıldırım, 2015).

Nitel analizi değerlendirme dişı bırakmadan yapılan niceliksel analiz araştırmacının değerlendirme kalitesini de yükseltecektir (Koçak ve Arun, 2006).

Nitekim yöntem olarak kullanılan içerik analiziyle belirlenen kapsam, sınırlılık ve örneklemin ortaya koyduğu bulguların değerlendirilmesi aşağıda yapılmıştır.

\section{Bulgular}

Büyükelçilerin Şahsi Twitter Hesaplarından ve Kurumsal Büyükelçilik Twitter Hesaplarından Harekât ile ilgili Yaptıkları Paylaşım Tablosu

Tablo 1. Türkiye Paris Büyükelçisi İsmail Hakkı Musa'nın şahsi Twitter hesabı paylaşımlari*

\begin{tabular}{|c|c|c|c|c|c|}
\hline \multicolumn{6}{|c|}{$\begin{array}{c}\text { Türkiye Paris Büyükelçisi } \\
\text { İsmail Hakkı Musa } \\
\text { Büyükelçinin kendi hesabı. } \\
\text { https://twitter.com/ihakkimusa } \\
\text { Hesap Açllış Tarihi: Ekim } 2019 \\
\text { Illk Tweet Atış Tarihi: } 15 \text { Ekim } 2019 \\
\text { Tweetler: } 58 \text { Takip Edilen: } 47 \text { Takipçiler: } 928 \text { Beğeni: } 5\end{array}$} \\
\hline $\begin{array}{c}\text { Harekât ile } \\
\text { ilgili } \\
\text { Atılan } \\
\text { Tweet } \\
\text { Sayısı } \\
\end{array}$ & $\begin{array}{c}\text { Atılan } \\
\text { Tweetlerin } \\
\text { Tarihi ve } \\
\text { Lisanı }\end{array}$ & $\begin{array}{c}\text { Atılan Tweetlerin } \\
\text { İçeriği }\end{array}$ & $\begin{array}{c}\text { Harekât } \\
\text { ile ilgili } \\
\text { Retweet } \\
\text { Sayısı }\end{array}$ & $\begin{array}{c}\text { Atılan } \\
\text { Retweetlerin } \\
\text { Tarihi ve } \\
\text { Lisanı }\end{array}$ & $\begin{array}{c}\text { Atılan } \\
\text { Retweetlerin } \\
\text { İçeriği }\end{array}$ \\
\hline 1 & $\begin{array}{l}31 \text { Ekim } \\
\text { 2019, } \\
\text { Fransizca }\end{array}$ & $\begin{array}{c}\text { Operasyon, } \\
\text { Türkiye'yi } \\
\text { güvenlik } \\
\text { hakkından ve } \\
\text { bölgeyi istikrara } \\
\text { kavuşturma } \\
\text { arzusundan feragat } \\
\text { etmeye zorlayan }\end{array}$ & 1 & $\begin{array}{c}15 \text { Ekim 2019, } \\
\text { Fransizca }\end{array}$ & $\begin{array}{c}\text { TurkishEmbassyP } \\
\text { aris } \\
\text { @TurquieParis } \\
\text { (T.C. Paris } \\
\text { Büyükelçiliği } \\
\text { resmi Twitter } \\
\text { hesabı) } \\
\text { Büyükelçi İsmail } \\
\text { Hakkı Musa, }\end{array}$ \\
\hline
\end{tabular}

\footnotetext{
Bulgular, Türkiye Paris Büyükelçisi İsmail Hakkı Musa'nın şahsi Twitter hesabı (https://twitter.com/ihakkimusa) üzerinden, 09 Ekim 2019 tarihi ve 14 Kasım 2019 tarihi arasında yapılan harekat ile ilgili paylaşımlardan elde edilmiştir.
} 
Kamu Diplomasisinde Dijital Dönüşüm: Büyükelçilerin Twitter Üzerinden Gerçekleştirdikleri Dijital Diplomasi Faaliyetlerinin İncelenmesi Mesut İris, Tansu Akdemir

\begin{tabular}{|c|c|c|c|c|c|}
\hline & & $\begin{array}{c}\text { temelsiz } \\
\text { eleştirilere, yönelik. }\end{array}$ & & & $\begin{array}{c}\text { Barış } \\
\text { Operasyonunun } \\
\text { Kaynağı } \\
\text { hakkında bilgi } \\
\text { vermek için bu } \\
\text { gece France } \\
\text { Info'ya konuştu. }\end{array}$ \\
\hline 2 & $\begin{array}{c}31 \text { Ekim } \\
\text { 2019, } \\
\text { Fransizca }\end{array}$ & $\begin{array}{c}\text { Operasyon } \\
\text { "Kürtleri" değil, } \\
\text { PYD / YPG / PKK } \\
\text { ve DAESH terör } \\
\text { örgütlerini hedef } \\
\text { allyor. }\end{array}$ & 2 & $\begin{array}{c}15 \text { Ekim 2019, } \\
\text { Fransizca }\end{array}$ & $\begin{array}{c}\text { TurkishEmbassyP } \\
\text { aris } \\
\text { @TurquieParis } \\
\text { (T.C. Paris } \\
\text { Büyükelçiliği } \\
\text { resmi Twitter } \\
\text { hesabı) } \\
\text { Büyükelçi İsmail } \\
\text { Hakkı Musa, bu } \\
\text { sabah Barış } \\
\text { Operasyonunun } \\
\text { Kaynağı } \\
\text { hakkında bilgi } \\
\text { vermek için } \\
\text { BFMTV'de } \\
\text { konuştu. }\end{array}$ \\
\hline 3 & $\begin{array}{c}31 \text { Ekim } \\
\text { 2019, } \\
\text { Fransizca }\end{array}$ & $\begin{array}{l}\text { Terörist örgütlerle } \\
\text { mücadele, başka } \\
\text { bir terörist örgüte } \\
\text { emanet edilemez. }\end{array}$ & 3 & $\begin{array}{c}15 \text { Ekim 2019, } \\
\text { Fransizca }\end{array}$ & $\begin{array}{c}\text { TurkishEmbassyP } \\
\text { aris } \\
\text { @TurquieParis } \\
\text { (T.C. Paris } \\
\text { Büyükelçiliği } \\
\text { resmi Twitter } \\
\text { hesabı) } \\
\text { Büyükelçi İsmail } \\
\text { Hakkı Musa, bu } \\
\text { sabah Barış } \\
\text { Operasyonunun } \\
\text { Kaynağı } \\
\text { hakkında bilgi } \\
\text { vermek için } \\
\text { LCI'da konustu. }\end{array}$ \\
\hline 4 & $\begin{array}{c}31 \text { Ekim } \\
\text { 2019, } \\
\text { Fransizca }\end{array}$ & $\begin{array}{c}\text { Türkiye'nin } \\
\text { mücadelesinin } \\
\text { yalnızca çıkarlarına } \\
\text { hizmet etmediğini, } \\
\text { bölgede terörist bir } \\
\text { "devlet" in } \\
\text { kurulmasını } \\
\text { önlemeyi } \\
\text { amaçladığı } \\
\text { hatırlatılmalıdır. }\end{array}$ & 4 & $\begin{array}{c}15 \text { Ekim 2019, } \\
\text { Fransizca }\end{array}$ & $\begin{array}{c}\text { TurkishEmbassyP } \\
\text { aris } \\
\text { @TurquieParis } \\
\text { (T.C. Paris } \\
\text { Büyükelçiliği } \\
\text { resmi Twitter } \\
\text { hesabı) } \\
\text { Büyükelçi Dr. } \\
\text { İsmail Hakkı } \\
\text { Musa, bu sabah } \\
\text { Barış }\end{array}$ \\
\hline
\end{tabular}




\begin{tabular}{|c|c|c|c|c|c|}
\hline & & & & & $\begin{array}{c}\text { Operasyonunun } \\
\text { Kaynağ } \\
\text { hakkında bilgi } \\
\text { vermek için } \\
\text { RMC'deki } \\
\text { Bourdin Direct } \\
\text { programinda } \\
\text { konuştu. }\end{array}$ \\
\hline 5 & $\begin{array}{c}1 \text { Kasim } \\
2019, \\
\text { Fransizca }\end{array}$ & $\begin{array}{l}\text { Dostlarımız ve } \\
\text { müttefiklerimizin } \\
\text { bilmesi gerekenler: } \\
\text { YPG, Türkiye'de } \\
\text { 40.000 ölü olan } \\
\text { terör örgütü } \\
\text { PKK'nın } \\
\text { Suriye'deki yan } \\
\text { kuruluşu. } \\
\text { Kurbanlarımız } \\
\text { diğgrlerinden daha } \\
\text { az merhamete } \\
\text { layık mı? } \\
\text { Türkiye, } \\
\text { vatandaşlarını, } \\
\text { başkalarıyla } \\
\text { yaptığı gibi, kendi } \\
\text { halkıla koruyor. }\end{array}$ & 5 & $\begin{array}{c}15 \text { Ekim 2019, } \\
\text { Fransızca }\end{array}$ & $\begin{array}{c}\text { TurkishEmbassyP } \\
\text { aris } \\
\text { @TurquieParis } \\
\text { (T.C. Paris } \\
\text { Büyükelçiliği } \\
\text { resmi Twitter } \\
\text { hesabı) } \\
\text { Büyükelçi Dr. } \\
\text { İsmail Hakkı } \\
\text { Musa, } \\
\text { \#Operationspeace } \\
\text { hakkında bilgi } \\
\text { vermek için } \\
\text { Fransa } 24 \\
\text { hakkında } \\
\text { konuştu. }\end{array}$ \\
\hline 6 & $\begin{array}{c}3 \text { Kasim } \\
2019, \\
\text { Fransizca }\end{array}$ & $\begin{array}{c}\text { Arkadaşlarımızın } \\
\text { ve } \\
\text { müttefiklerimizin } \\
\text { cevap } \\
\text { verebilecekleri } \\
\text { basit ve meşru } \\
\text { soru: YPG / PYD / } \\
\text { PKK terör } \\
\text { örgütünü arkadaş } \\
\text { ve müttefik olarak } \\
\text { görürlerse, o } \\
\text { zaman Türkiye'yi } \\
\text { nasıl görüyorlar? }\end{array}$ & 6 & $\begin{array}{c}15 \text { Ekim 2019, } \\
\text { Fransizca }\end{array}$ & $\begin{array}{c}\text { TurkishEmbassyP } \\
\text { aris } \\
\text { @TurquieParis } \\
\text { (T.C. Paris } \\
\text { Büyükelçiliği } \\
\text { resmi Twitter } \\
\text { hesabı) } \\
\text { Büyükelçi Dr. } \\
\text { İsmail Hakkı } \\
\text { Musa, Barış } \\
\text { Operasyonunun } \\
\text { Kaynağı } \\
\text { hakkında bilgi } \\
\text { vermek için BFM } \\
\text { TV'de konuştu. }\end{array}$ \\
\hline
\end{tabular}


Kamu Diplomasisinde Dijital Dönüşüm: Büyükelçilerin Twitter Üzerinden Gerçekleştirdikleri Dijital Diplomasi Faaliyetlerinin İncelenmesi Mesut İris, Tansu Akdemir

\begin{tabular}{|c|c|c|c|c|c|}
\hline 7 & $\begin{array}{c}4 \text { Kasım } \\
\text { 2019, } \\
\text { Fransizca }\end{array}$ & $\begin{array}{l}\text { Tel Abyad ve Ras } \\
\text { el-Ain'da PKK / } \\
\text { YPG terör örgütü } \\
\text { zulmüne son } \\
\text { verildi. } \\
\text { Artık Suriyeli } \\
\text { kardeşlerimizin } \\
\text { ülkesine ve } \\
\text { topraklarına } \\
\text { gönüllü olarak ve } \\
\text { güvenle geri } \\
\text { dönmeleri } \\
\text { mümkün. }\end{array}$ & 7 & $\begin{array}{l}18 \text { Ekim 2019, } \\
\text { İngilizce }\end{array}$ & $\begin{array}{c}\text { Fahrettin Altun } \\
\text { @fahrettinaltun } \\
\text { (Illetişim Başkanı, } \\
\text { Türkiye } \\
\text { Cumhuriyeti) } \\
\text { Bu anlaşmayla } \\
\text { Türkiye, } \\
\text { Başkanımızın } \\
\text { güçlü liderliği ve } \\
\text { TSK'nın yerdeki } \\
\text { başarısı sayesinde } \\
\text { operasyonun } \\
\text { temel hedeflerine } \\
\text { hızlı bir şekilde } \\
\text { ulaşma, yani } \\
\text { sınırımızı } \\
\text { teröristlerden } \\
\text { uzaklaştırma ve } \\
\text { güvenli bir bölge } \\
\text { oluşturma } \\
\text { yönünde önemli } \\
\text { bir adım attı. }\end{array}$ \\
\hline 8 & $\begin{array}{c}5 \text { Kasım } \\
\text { 2019, } \\
\text { Fransizca }\end{array}$ & $\begin{array}{c}\text { Suriye } \\
\text { meselesinde, } \\
\text { medya ve bazı } \\
\text { siyasi çevreler } \\
\text { yerdeki } \\
\text { gerçekliklerden } \\
\text { uzak tutulan bir } \\
\text { efsaneye neden } \\
\text { oluyor. } \\
\text { Kritik olmayan bir } \\
\text { şekilde kabul } \\
\text { edilen bu program } \\
\text { basit ve özellikle } \\
\text { tehlikelidir. } \\
\text { Avrupa'nın } \\
\text { güvenlik } \\
\text { çıarlarına } \\
\text { aykırıdır. }\end{array}$ & 8 & $\begin{array}{l}19 \text { Ekim 2019, } \\
\text { İngilizce }\end{array}$ & $\begin{array}{c}\text { Mevlüt } \\
\text { Çavuşoğlu } \\
\text { @MevlutCavusog } \\
\text { lu } \\
\text { (T.C. Dışişleri } \\
\text { Bakanı) } \\
\text { Yerinde tespit! } \\
\\
\text { Well said! } \\
\text { Video Paylaşımı. } \\
\text { Hudson } \\
\text { Enstitüsünde } \\
\text { Suriye } \\
\text { operasyonuna } \\
\text { yönelik } \\
\text { katılımcıların } \\
\text { görüşleri. }\end{array}$ \\
\hline 9 & $\begin{array}{c}5 \text { Kasim } \\
\text { 2019, } \\
\text { Fransizca }\end{array}$ & $\begin{array}{l}\text { Operasyon sadece } \\
\text { terör örgütlerini } \\
\text { hedef alıyor. Hiçbir } \\
\text { sivil hedef } \\
\text { alınmadı, tarihi bir } \\
\text { anit ya da ibadet } \\
\text { yeri tahrip } \\
\text { edilmedi. }\end{array}$ & 9 & $\begin{array}{c}19 \text { Ekim 2019, } \\
\text { Türkçe }\end{array}$ & $\begin{array}{l}\text { ANADOLU } \\
\text { AJANSI } \\
\text { @anadoluajansi } \\
\text { “PKK'nın neden } \\
\text { yasaklandığını } \\
\text { söyleyeyim; } \\
\text { şantajla para } \\
\text { toplama, silah } \\
\text { ticareti, }\end{array}$ \\
\hline
\end{tabular}




\begin{tabular}{|c|c|c|c|c|c|}
\hline & & $\begin{array}{l}\text { Tal Abyad ve Ras } \\
\text { el-Ain'deki kiliseler } \\
\text { etkilenmedi. }\end{array}$ & & & $\begin{array}{c}\text { uyuşturucu } \\
\text { ticareti. Hepsini } \\
\text { de her zaman } \\
\text { Türkiye'de } \\
\text { mevcut iç savaşı } \\
\text { finanse etmek için } \\
\text { yaptı” } \\
\text { Eski Alman } \\
\text { bakan, terör } \\
\text { örgütü PKK'nın } \\
\text { suçlarını anlattı } \\
\text { http://v.aa.com.tr/ } \\
\text { 1619557 } \\
\end{array}$ \\
\hline 10 & $\begin{array}{l}5 \text { Kasım } \\
\text { 2019, } \\
\text { Fransizca }\end{array}$ & $\begin{array}{l}\text { Bağdadi'nin kız } \\
\text { kardeşinin Türk } \\
\text { kuvvetleri } \\
\text { tarafından } \\
\text { tutuklanması, } \\
\text { terörizmle her } \\
\text { türlü biçim ve } \\
\text { tezahürle mücadele } \\
\text { etme } \\
\text { kararlılığımızın } \\
\text { yeni bir kanıtı. }\end{array}$ & 10 & $\begin{array}{l}19 \text { Ekim 2019, } \\
\text { Türkçe }\end{array}$ & $\begin{array}{c}\text { Mevlüt } \\
\text { Çavuşoğlu } \\
\text { @MevlutCavusog } \\
\text { lu } \\
\text { (T.C. Dışişleri } \\
\text { Bakanı) } \\
\text { Gerçekleri; } \\
\text { çekinmeden, } \\
\text { cesurca } \\
\text { söyleyenler de } \\
\text { var! } \\
\text { @sigmargabriel } \\
\text { (Eski Alman } \\
\text { bakan'ın PKK ile } \\
\text { ilgili } \\
\text { söylemlerinin yer } \\
\text { aldığı video } \\
\text { paylaşımı) } \\
\end{array}$ \\
\hline 11 & $\begin{array}{l}5 \text { Kasım } \\
\text { 2019, } \\
\text { Fransizca }\end{array}$ & $\begin{array}{c}\text { DAEŞ ile } \\
\text { mücadelede } \\
\text { verdiğimiz } \\
\text { taahhüdümüzden } \\
\text { şüphelenenler için, } \\
\text { envanter: } \\
\text { - } 2017 \text { yılında "Fırat } \\
\text { Kalkanı" ve 2018'de } \\
\text { "Rameau d'Olivier" } \\
\text { Operasyonu } \\
\text { sırasında Türk } \\
\text { Ordusu tarafından } \\
\text { nötralize edilen } \\
\text { 4.000'den fazla } \\
\text { terörist, } 1 / 3\end{array}$ & 11 & $\begin{array}{l}19 \text { Ekim 2019, } \\
\text { İngilizce }\end{array}$ & $\begin{array}{c}\text { EHA News } \\
\text { @eha_news } \\
\text { Almanya'nın eski } \\
\text { Şansölye } \\
\text { Yardımcısı } \\
\text { Sigmar Gabriel } \\
\text { @sigmargabriel } \\
\text { "Suriye iç savaşı } \\
\text { başladığında, } \\
\text { Erdoğan Esad'ın } \\
\text { halkını } \\
\text { bombalamasını } \\
\text { engellemek için } \\
\text { Suriye üzerinden } \\
\text { bir uçuş bölgesi } \\
\text { önermedi, ancak } \\
\text { ilk reddedenler } \\
\end{array}$ \\
\hline
\end{tabular}


Kamu Diplomasisinde Dijital Dönüşüm: Büyükelçilerin Twitter Üzerinden Gerçekleştirdikleri Dijital Diplomasi Faaliyetlerinin İncelenmesi Mesut İris, Tansu Akdemir

\begin{tabular}{|c|c|c|c|c|c|}
\hline & & & & & $\begin{array}{l}\text { Almanya ve } \\
\text { Avrupa idi." }\end{array}$ \\
\hline 12 & $\begin{array}{c}5 \text { Kasım } \\
\text { 2019, } \\
\text { Fransizca }\end{array}$ & $\begin{array}{l}\text { - Halihazırda Türk } \\
\text { hapishanelerinde } \\
\text { bulunan ve bunlara } \\
\text { bağlı ülkeler } \\
\text { tarafından geri } \\
\text { alınmayı bekleyen } \\
737 \text { yabancı uyruk } \\
\text { olmak üzere } 1.149 \\
\text { DAEŞ üyesi, } \\
\text { - Türkiye } \\
\text { topraklarına } \\
\text { erişimin } 141 \text { farklı } \\
\text { millet tarafından } \\
\text { radikalleşmesi } \\
\text { muhtemel } 77.000 \\
\text { kişiye } \\
\text { yasaklanması, } 2 / 3\end{array}$ & 12 & $\begin{array}{c}21 \text { Ekim 2019, } \\
\text { Fransizca }\end{array}$ & $\begin{array}{l}\text { TurkishEmbassyP } \\
\text { aris } \\
\text { @TurquieParis } \\
\text { (T.C. Paris } \\
\text { Büyükelçiliği } \\
\text { resmi Twitter } \\
\text { hesabı) } \\
\text { Türkiye-Amerika } \\
\text { Birleşik Devletleri } \\
\text { Kuzeydoğu } \\
\text { Suriye Hakkında } \\
\text { Ortak Açıklama }\end{array}$ \\
\hline 13 & $\begin{array}{c}5 \text { Kasim } \\
\text { 2019, } \\
\text { Fransizca }\end{array}$ & $\begin{array}{c}\text { - Sınır } \\
\text { kontrollerinden } \\
\text { sonra } 7.500 \text { 'den } \\
\text { fazla kişi menşe } \\
\text { ülkelerine geri } \\
\text { döndü. } \\
\text { Bu taahhüt } \\
\text { doğrudan Avrupa } \\
\text { güvenliğine } \\
\text { katkıda bulunur. } \\
\text { Başka yerlerden ne } \\
\text { haber? } 3 / 3\end{array}$ & 13 & $\begin{array}{l}26 \text { Ekim 2019, } \\
\text { İngilizce }\end{array}$ & $\begin{array}{c}\text { Serdar KILIÇ } \\
\text { @serdarkilic9 } \\
\text { (Ambassador of } \\
\text { the Republic of } \\
\text { Turkey to the } \\
\text { United States } \\
\text { /ABD nezdinde } \\
\text { Türkiye } \\
\text { Cumhuriyeti } \\
\text { Büyükelçisi) } \\
\text { Katılan herkesin } \\
\text { gerçekte kim } \\
\text { olduğunu ve ne } \\
\text { anlama geldiğini } \\
\text { bildiğinden } \\
\text { eminim, ancak } \\
\text { YPG'den } \\
\text { “general” } \\
\text { Mazlum / Ferhat } \\
\text { Abdi Şahin / } \\
\text { Şahin Cilo'nun bir } \\
\text { kez daha kim } \\
\text { olduğunun } \\
\text { bilgisini } \\
\text { paylaşmak } \\
\text { faydalı olacaktır. } \\
\text { kişi önceden } \\
\text { aydinlanmadılar } \\
\text { anı iddia edebilir. }\end{array}$ \\
\hline
\end{tabular}




\begin{tabular}{|c|c|c|c|c|c|}
\hline 14 & $\begin{array}{c}6 \text { Kasım } \\
\text { 2019, } \\
\text { Fransizca }\end{array}$ & $\begin{array}{c}\text { \#DAEŞ ile } \\
\text { mücadelemiz } \\
\text { durmadan devam } \\
\text { ediyor! } \\
\text { Bu kez, Türk } \\
\text { kuvvetleri } \\
\text { tarafından } \\
\text { tutuklanan Ebu } \\
\text { Bekir El } \\
\text { Bağdadi'nin } \\
\text { karısıydı. } \\
\text { Büyük bir hayran } \\
\text { kitlesiyle } \\
\text { haykırılmayan ama } \\
\text { bilenler için önemli } \\
\text { olan bir haber ... } \\
\end{array}$ & 14 & $\begin{array}{c}31 \text { Ekim 2019, } \\
\text { Türkçe }\end{array}$ & $\begin{array}{c}\text { T.C. Dışişleri } \\
\text { Bakanlığı } \\
\text { @TC_Disisleri } \\
\text { (T.C. Dışişleri } \\
\text { Bakanlığı Resmi } \\
\text { Twitter sayfası) } \\
\text { Fransız } \\
\text { Parlamentosu'nu } \\
\text { n Barış Pınarı } \\
\text { Harekâtı } \\
\text { Konusunda } \\
\text { Kabul Ettiği } \\
\text { Kararlar Hk. }\end{array}$ \\
\hline 15 & $\begin{array}{c}7 \text { Kasım } \\
\text { 2019, } \\
\text { Fransizca }\end{array}$ & $\begin{array}{c}\text { "Türkiye'nin } \\
\text { Suriye'deki } \\
\text { Kürtlerle hiçbir } \\
\text { sorunu yok, } \\
\text { Türkiye'nin PKK } \\
\text { ile sorunu var. " } \\
\text { Nechirvan Barzani } \\
\text { \#GRKI Başkanı } \\
\text { Yorum } \\
\text { gerektirmeyen bir } \\
\text { ifade. } \\
\end{array}$ & 15 & $\begin{array}{c}1 \text { Kasim 2019, } \\
\text { Fransizca }\end{array}$ & $\begin{array}{c}\text { TRT Français } \\
\text { @TRTFrancais } \\
\text { Suriye'deki Türk- } \\
\text { Rus ortak } \\
\text { devriyeleri }\end{array}$ \\
\hline 16 & $\begin{array}{c}8 \text { Kasım } \\
\text { 2019, } \\
\text { Fransizca }\end{array}$ & $\begin{array}{c}\text { Türkiye'nin } \\
\text { Suriye'deki } \\
\text { eyleminin temel } \\
\text { amaçları: } \\
\text { Terör örgütlerine } \\
\text { karşı mücadele } \\
\text { \#DAESH, \# PKK- } \\
\text { YPG. } \\
\text { Suriyeli } \\
\text { göçmenlerin } \\
\text { ülkelerine gönüllü } \\
\text { ve güvenli geri } \\
\text { dönüşleri. } \\
\text { Bölgemizin } \\
\text { güvenlik ve refahı, } \\
\text { dostlarımız ve } \\
\text { müttefiklerimizle } \\
\text { işbirliği içinde. }\end{array}$ & 16 & $\begin{array}{c}2 \text { Kasım 2019, } \\
\text { İngilizce }\end{array}$ & $\begin{array}{c}\text { Ibrahim Kalin } \\
\text { @ikalin1 } \\
\text { YPG teröristleri } \\
\text { Tal Abyad'da bir } \\
\text { pazarda } \\
\text { düzenlediği } \\
\text { saldırıda bugün } \\
\text { 13 kişiyi öldürdü } \\
\text { ve } 20 \text { kişiyi } \\
\text { yaraladı. } \\
\text { Bu bir kez daha } \\
\text { bu terör } \\
\text { örgütünün gerçek } \\
\text { yüzünü } \\
\text { gösteriyor. } \\
\text { Türkiye terörle } \\
\text { mücadeleye her } \\
\text { türlü şekli ve }\end{array}$ \\
\hline
\end{tabular}


Kamu Diplomasisinde Dijital Dönüşüm: Büyükelçilerin Twitter Üzerinden Gerçekleştirdikleri Dijital Diplomasi Faaliyetlerinin İncelenmesi Mesut İris, Tansu Akdemir

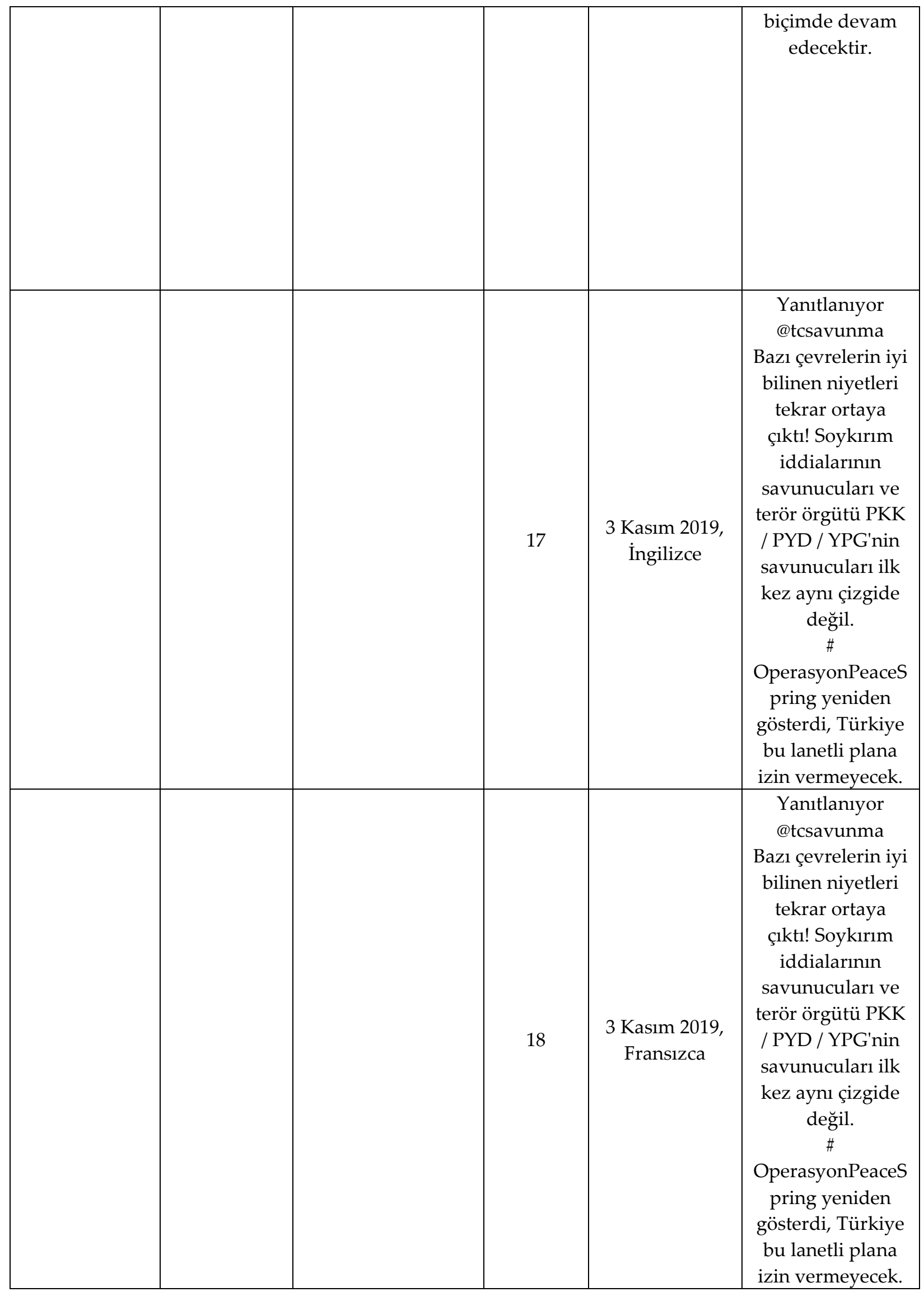




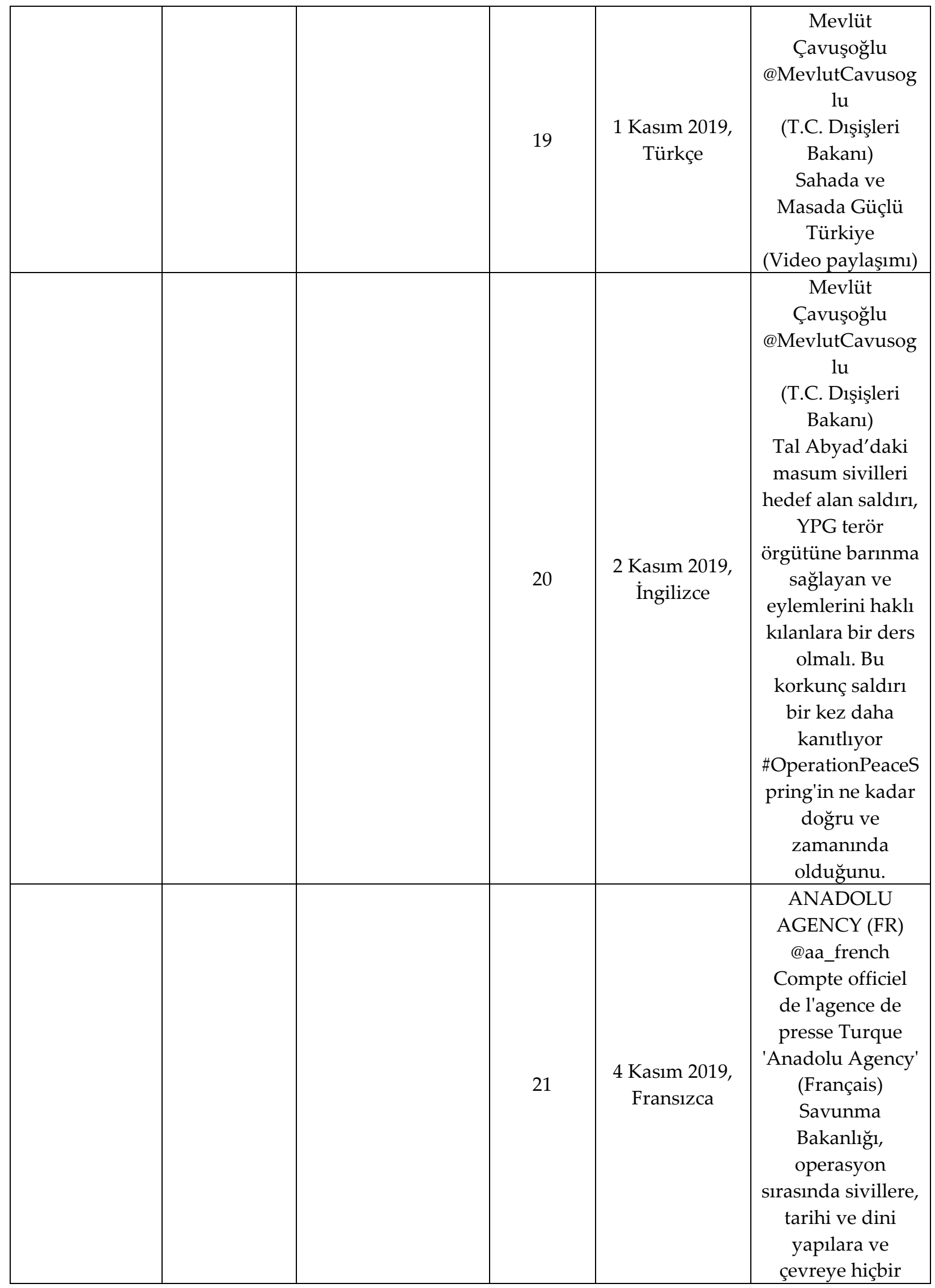


Kamu Diplomasisinde Dijital Dönüşüm: Büyükelçilerin Twitter Üzerinden Gerçekleştirdikleri Dijital Diplomasi Faaliyetlerinin İncelenmesi Mesut İris, Tansu Akdemir

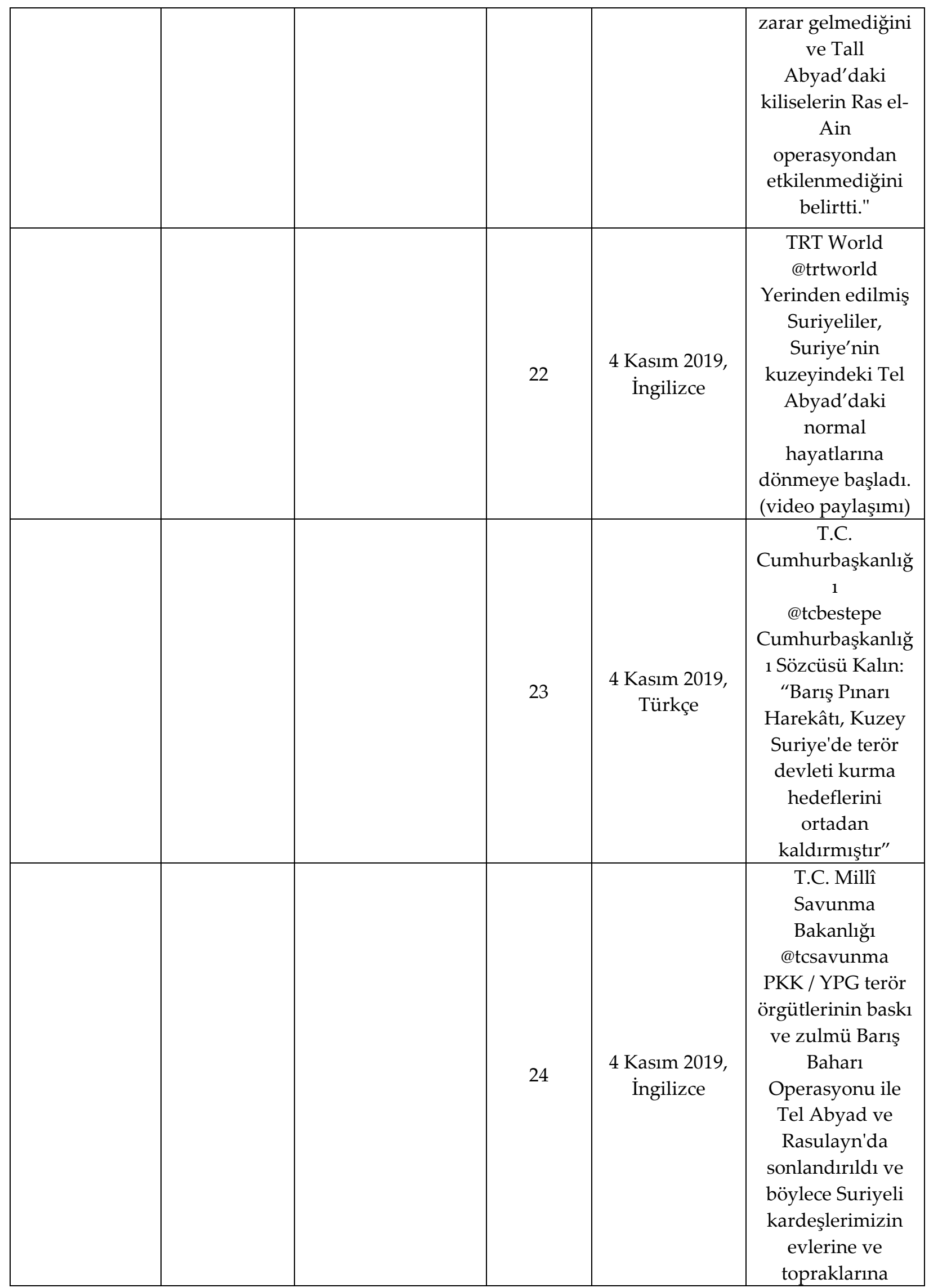




\begin{tabular}{|l|l|l|l|c|}
\hline & & & & $\begin{array}{c}\text { gönüllü ve } \\
\text { güvenli bir } \\
\text { şekilde geri } \\
\text { dönmelerinin } \\
\text { yolu açıld. } \\
\text { (video paylaşımı) }\end{array}$ \\
& & & & \\
\hline
\end{tabular}

Türkiye Paris Büyükelçisi İsmail Hakkı Musa'nın şahsi Twitter hesabı üzerinden harekât ile ilgili paylaşımları yukarıda görüleceği üzere sıralanmıştır. Büyükelçinin harekât ile ilgili toplam 16 Tweeti, 24 Retweeti vardır. Tweetlerin içeriğine bakıldığı zaman, Türkiye'nin Harekâtı gerçekleştirme nedenleri üzerinde durulduğu görülmektedir. Ayrıca tweetlerde Harekâtı n özellikle terör örgütlerine yönelik gerçekleştirildiğinin altının çizilmesi, uluslararası platformda harekâta karşı oluşturulmaya çalışılan kamuoyuna karşı Harekâtı n meşruluğu üzerine yapılan faaliyetlere örnektir. Nitekim Avrupa'nın güvenliği ve DAEŞ ile olan mücadelenin de Türkiye'nin gerçekleştirdiği Harekâtı n başlıca nedenlerinden olduğu tweetlerde bulunmaktadır.

Retweetler ise Türkiye'nin resmi twitter hesaplarının ve hükümet yetkililerinin paylaşımlarından oluşmaktadır. Özellikle Dışişleri Bakanı Mevlüt Çavuşoğlu, Cumhurbaşkanlığı Sözcüsü İbrahim Kalın ve İletişim Başkanlığı gibi ilgili hükümet yetkililerinin dijital diplomasi faaliyetlerinin takip edildiği ve anlık olarak retweetlendiği görülmektedir.

Nitekim büyükelçinin şahsi twitter hesabını Ekim 2019 tarihinde açması ve takipçi sayısının 1.232 olması (Twitter, 2019) iletişim teknolojilerinin yetkililerce yeterince kullanılmadığının göstergesidir. ABD Fransa Büyükelçisi'nin şahsi twitter hesabını Ekim 2014'te açması ve takipçi sayısının 13 bin üzerinde olması (Twitter, 2019) dijital diplomasi faaliyetlerinde sosyal medya ve internetin doğru kullanımının önemini göstermektedir. Günümüzde, “'Beğen’lerin, 'Retweet'lerin ve 'Hashtag'lerin yalnızca insanlar arasındaki özel etkileşim için olmadığı, bunların küresel gündemi şekilllendirebileceği” (Kurt, 2018:25) ifade edilmektedir. Ne kadar çok kişiye, ne kadar hızlı ulaşabilir ve bilgi aktarabilirseniz o denli güçlüsünüzdür. 
Kamu Diplomasisinde Dijital Dönüşüm:

Tablo 2. Türkiye Paris Büyükelçiliği Büyükelçilik resmi Twitter hesabı paylaşımları*

\begin{tabular}{|c|c|c|c|c|c|}
\hline \multicolumn{6}{|c|}{$\begin{array}{c}\text { Türkiye Paris Büyükelçiliği } \\
\text { Büyükelçilik Resmi Twitter Hesabı } \\
\text { TurkishEmbassyParis } \\
\text { @TurquieParis } \\
\text { Hesap Açılış Tarihi: Nisan } 2010 \\
\text { Tweetler: } 3.077 \text { Takip Edilen: } 197 \text { Takipçiler: } 5.972\end{array}$} \\
\hline $\begin{array}{l}\text { Harekât } \\
\text { ile ilgili } \\
\text { Atılan } \\
\text { Tweet } \\
\text { Sayısı }\end{array}$ & $\begin{array}{c}\text { Atılan } \\
\text { Tweetlerin } \\
\text { Tarihi ve } \\
\text { Lisanı }\end{array}$ & Atılan Tweetlerin İçeriği & $\begin{array}{c}\text { Harekât } \\
\text { ile ilgili } \\
\text { Retweet } \\
\text { Sayısı }\end{array}$ & $\begin{array}{c}\text { Atılan } \\
\text { Retweetlerin } \\
\text { Tarihi ve } \\
\text { Lisanı }\end{array}$ & $\begin{array}{c}\text { Atılan } \\
\text { Retweetlerin } \\
\text { İçeriği }\end{array}$ \\
\hline 1 & $\begin{array}{c}9 \text { Ekim } \\
\text { 2019, } \\
\text { Fransizca }\end{array}$ & $\begin{array}{l}\text { Fahrettin Altun: } \\
\text { "Uluslararası toplum, } \\
\text { Türkiye'nin kuzeydoğu } \\
\text { Suriye planını } \\
\text { desteklemeli." }\end{array}$ & 1 & $\begin{array}{c}7 \text { Ekim 2019, } \\
\text { Türkçe }\end{array}$ & $\begin{array}{c}\text { Mevlüt Çavuşoğlu } \\
\text { @MevlutCavusoglu } \\
\text { (T.C. Dışişleri Bakanı) } \\
\text { Suriye' deki krizin } \\
\text { başından beri bu ülkenin } \\
\text { toprak bütünlüğünü } \\
\text { destekledik, bundan } \\
\text { sonra da desteklemeye } \\
\text { devam edeceğiz. Bölgeyi } \\
\text { teröristlerden } \\
\text { temizleyerek ülkemizin } \\
\text { bekasını ve güvenliğini } \\
\text { sağlamaya kararlıyı. } \\
\text { Suriye'ye de huzur,barış } \\
\text { ve istikrarın gelmesine } \\
\text { katkı sağlayacağı. } \\
\end{array}$ \\
\hline 2 & $\begin{array}{l}10 \text { Ekim } \\
\text { 2019, } \\
\text { Fransizca }\end{array}$ & $\begin{array}{l}\text { \#BarışPınarıHarekâtı } \\
\text { \#OpérationSourcedePaix } \\
\text { (görsel paylaşımı ile adım } \\
\text { adım operasyon } \\
\text { açıklaması) }\end{array}$ & 2 & $\begin{array}{c}8 \text { Ekim 2019, } \\
\text { Fransizca }\end{array}$ & $\begin{array}{c}\text { Turkish MFA French } \\
\text { @MFATurkeyFrench } \\
\text { Dişişleri Bakanlığı } \\
\text { Sözcüsü Hami Aksoy'un } \\
\text { Fırat'ın Doğusunda } \\
\text { Kurulacak Güvenlik } \\
\text { Bölgesi Konusunda } \\
\text { Yabancı Memurların } \\
\text { Görüşleri }\end{array}$ \\
\hline 3 & $\begin{array}{l}10 \text { Ekim } \\
\text { 2019, } \\
\text { Fransizca }\end{array}$ & $\begin{array}{l}\text { TR } 9 \text { Ekim'de Suriye'nin } \\
\text { kuzeyindeki askeri terörle } \\
\text { mücadele operasyonunu } \\
\text { yeni başlattı. } \\
\text { \#OperationSourcePeace'in } \\
\text { amacını, içeriğini ve } \\
\text { kapsamını daha iyi }\end{array}$ & 3 & $\begin{array}{c}9 \text { Ekim 2019, } \\
\text { Fransizca }\end{array}$ & $\begin{array}{l}\text { ANADOLU AGENCY } \\
\qquad(\text { FR) } \\
\text { @aa_french } \\
5 \text { soruda Barış Pınarı } \\
\text { Harekâtı }\end{array}$ \\
\hline
\end{tabular}

* Bulgular, Türkiye Paris Büyükelçiliği resmi Twitter hesabı (https://twitter.com/turquieparis) üzerinden, 09 Ekim 2019 tarihi ve 14 Kasım 2019 tarihi arasında yapılan harekat ile ilgili paylaşımlardan elde edilmiştir. 


\begin{tabular}{|c|c|c|c|c|c|}
\hline & & $\begin{array}{l}\text { anlamak için bazı temel } \\
\text { noktaların altının } \\
\text { çizilmesi gerekir. } \\
\text { (facebook linki paylaşımı) }\end{array}$ & & & \\
\hline 4 & $\begin{array}{c}10 \text { Ekim } \\
\text { 2019, } \\
\text { Fransizca }\end{array}$ & $\begin{array}{c}\text { \#OperationSourceDePaix } \\
\text { (Anadolu Ajansı FR } \\
\text { paylaşımı) } \\
\text { Oktay: Türkiye sivilleri } \\
\text { kurtarmaya duyarlı. YPG } \\
\text { / PKK, bir bebek de dahil } \\
\text { olmak üzere } 6 \text { sivil } \\
\text { öldürdü. Bütün dünya } \\
\text { farkı anlamalı. Bir yanda } \\
\text { teröristlerle savaşan } \\
\text { sorumlu bir devlet, diğer } \\
\text { yanda bir terör örgütü } \\
\text { var. } \\
\end{array}$ & 4 & $\begin{array}{c}9 \text { Ekim 2019, } \\
\text { Fransizca }\end{array}$ & $\begin{array}{c}\text { ANADOLU AGENCY } \\
\text { (FR) } \\
\text { @aa_french } \\
\text { Suriye'de Barış Pınarı } \\
\text { Operasyonu: Türk } \\
\text { Ordusu sadece } \\
\text { teröristleri hedef alıyor }\end{array}$ \\
\hline 5 & $\begin{array}{l}10 \text { Ekim } \\
\text { 2019, } \\
\text { Türkçe }\end{array}$ & $\begin{array}{l}\text { Büyükelçi Dr. İsmail } \\
\text { Hakkı Musa, RTL France } \\
\text { radyo kanalında } \\
\text { yayınlanan mülakatında } \\
\text { \#BarışPınarıHarekâtı } \\
\text { hakkında bilgi vermiştir. } \\
\text { \#OperationSourceDePaix }\end{array}$ & 5 & $\begin{array}{c}9 \text { Ekim 2019, } \\
\text { Fransizca }\end{array}$ & $\begin{array}{c}\text { ANADOLU AGENCY } \\
\text { (FR) } \\
\text { @aa_french } \\
\text { \# Türk İçişleri Bakanı, } \\
\text { \#Soylu: Suriye'deki Barış } \\
\text { Pınarı Operasyonu bir } \\
\text { savaş değil. Terörizmle } \\
\text { mücadele, sınırların } \\
\text { ötesinde bir operasyon. } \\
\text { Türkiye, bir terörist } \\
\text { kampını imha etmek için } \\
\text { meşru bir operasyon } \\
\text { yürütüyor. }\end{array}$ \\
\hline 6 & $\begin{array}{c}11 \text { Ekim } \\
\text { 2019, } \\
\text { Fransizca }\end{array}$ & $\begin{array}{l}\text { Büyükelçi İsmail Hakkı } \\
\text { Musa, Barışı Pınarı } \\
\text { Operasyonu hakkında } \\
\text { bilgi vermek için RTL } \\
\text { Fransa'da konuştu. } \\
\text { \#OperationSourceDePaix }\end{array}$ & 6 & $\begin{array}{c}9 \text { Ekim 2019, } \\
\text { Fransizca }\end{array}$ & $\begin{array}{c}\text { ANADOLU AGENCY } \\
\text { (FR) } \\
\text { @aa_french } \\
\text { Erdoğan: Barış Pınarı } \\
\text { Operasyonu ile } \\
\text { yaratacağımız güvenli } \\
\text { bölge sayesinde Suriyeli } \\
\text { mültecilerin evlerine } \\
\text { dönmelerini } \\
\text { sağlayacağı. }\end{array}$ \\
\hline 7 & $\begin{array}{c}11 \text { Ekim } \\
\text { 2019, } \\
\text { İngilizce }\end{array}$ & $\begin{array}{c}\text { Büyükelçi Dr. İsmail } \\
\text { Hakkı Musa, RTL France } \\
\text { radyo kanalında } \\
\text { yayınlanan mülakatında } \\
\text { \#BarışınarıHarekâtı } \\
\text { hakkında bilgi vermiştir. } \\
\text { \#OperationSourceDePaix }\end{array}$ & 7 & $\begin{array}{l}10 \text { Ekim } \\
\text { 2019, } \\
\text { Fransizca }\end{array}$ & $\begin{array}{c}\text { ANADOLU AGENCY } \\
\text { (FR) } \\
\text { @aa_french } \\
\text { Terör örgütlerine yakın } \\
\text { İnternet kullanıcılarının } \\
\text { manipüle etme } \\
\text { girişimleri } \\
\end{array}$ \\
\hline
\end{tabular}


Kamu Diplomasisinde Dijital Dönüşüm: Büyükelçilerin Twitter Üzerinden Gerçekleştirdikleri Dijital Diplomasi Faaliyetlerinin İncelenmesi Mesut İris, Tansu Akdemir

\begin{tabular}{|c|c|c|c|c|c|}
\hline & & & & & $\begin{array}{l}\text { http://v.aa.com.tr/1607926 } \\
\text { \# OperationSourceDePaix }\end{array}$ \\
\hline 8 & $\begin{array}{c}11 \text { Ekim } \\
\text { 2019, } \\
\text { Türkçe }\end{array}$ & $\begin{array}{c}\text { Büyükelçi Dr. İsmail } \\
\text { Hakkı Musa, bu sabah } \\
\text { France Info radyo } \\
\text { kanalında yayınlanan } \\
\text { mülakatında Barış Pınarı } \\
\text { Harekâtı hakkında bilgi } \\
\text { vermiştir. } \\
\text { \#BarışPınarıHarekâtı }\end{array}$ & 8 & $\begin{array}{c}10 \text { Ekim } \\
2019, \\
\text { Fransizca }\end{array}$ & $\begin{array}{c}\text { ANADOLU AGENCY } \\
(\mathrm{FR}) \\
\text { @aa_french } \\
\text { Çavuşoğlu: teröristler, } \\
\text { Suriye'deki tek endişemiz }\end{array}$ \\
\hline 9 & $\begin{array}{c}11 \text { Ekim } \\
\text { 2019, } \\
\text { Fransizca }\end{array}$ & $\begin{array}{c}\text { Büyükelçi Dr. İsmail } \\
\text { Hakkı Musa, bu sabah } \\
\text { France Info radyo } \\
\text { kanalında yayınlanan } \\
\text { mülakatında Barış Pınarı } \\
\text { Harekâtı hakkında bilgi } \\
\text { vermiştir. } \\
\text { \#BarışPınarıHarekâtı }\end{array}$ & 9 & $\begin{array}{c}10 \text { Ekim } \\
2019, \\
\text { Fransizca }\end{array}$ & $\begin{array}{c}\text { ANADOLU AGENCY } \\
\text { (FR) } \\
\text { @aa_french } \\
\text { "\# YPG / \# PKK } \\
\text { Süryanileri tehdit ediyor } \\
\text { ve çocukları kaçırıyor" }\end{array}$ \\
\hline 10 & $\begin{array}{c}11 \text { Ekim } \\
\text { 2019, } \\
\text { İngilizce }\end{array}$ & $\begin{array}{c}\text { Büyükelçi Dr. İsmail } \\
\text { Hakkı Musa, bu sabah } \\
\text { France Info radyo } \\
\text { kanalında yayınlanan } \\
\text { mülakatında Barış Pınarı } \\
\text { Harekâtı hakkında bilgi } \\
\text { vermiştir. } \\
\text { \#BarışPınarıHarekâtı }\end{array}$ & 10 & $\begin{array}{c}10 \text { Ekim } \\
2019, \\
\text { Fransizca }\end{array}$ & $\begin{array}{c}\text { ANADOLU AGENCY } \\
\text { (FR) } \\
\text { @aa_french } \\
\text { YPG / PKK destekçileri } \\
\text { kamuoyunu manipüle } \\
\text { ediyor } \\
\text { http://v.aa.com.tr/1608325 }\end{array}$ \\
\hline 11 & $\begin{array}{c}11 \text { Ekim } \\
\text { 2019, } \\
\text { Fransizca }\end{array}$ & $\begin{array}{c}\text { \#OperationSourceDePaix } \\
\text { (haber paylaşımı) }\end{array}$ & 11 & $\begin{array}{c}10 \text { Ekim } \\
\text { 2019, } \\
\text { Fransizca }\end{array}$ & $\begin{array}{c}\text { ANADOLU AGENCY } \\
\text { (FR) } \\
\text { @aa_french } \\
\text { Erdoğan: "Geçtiğimiz } 4 \\
\text { yılda, sınırda } 8500 \text { olmak } \\
\text { üzere } 16.000 \text { teröristi } \\
\text { nötralize ettik" }\end{array}$ \\
\hline 12 & $\begin{array}{c}11 \text { Ekim } \\
\text { 2019, } \\
\text { Fransizca }\end{array}$ & $\begin{array}{c}\text { NATO Genel Sekreteri } \\
\text { Jens Stoltenberg, "Hiçbir } \\
\text { NATO üyesi Orta } \\
\text { Doğu'dan saldırılara } \\
\text { Türkiye kadar maruz } \\
\text { kalmadı ve Türkiye } \\
\text { terörle mücadelede } \\
\text { önemli bir oyuncu. } \\
\text { özellikle de DAEŞ'le } \\
\text { mücadele. " } \\
\text { (haber paylaşımı) }\end{array}$ & 12 & $\begin{array}{c}11 \text { Ekim } \\
\text { 2019, } \\
\text { Fransizca }\end{array}$ & $\begin{array}{c}\text { ANADOLU AGENCY } \\
\text { (FR) } \\
\text { @aa_french } \\
\text { Stoltenberg: "NATO } \\
\text { Türkiye'nin müttefiki } \\
\text { Türkiye'yi desteklemeye } \\
\text { devam edecek, hepimiz } \\
\text { için önemli bir } \\
\text { mücadelenin ön } \\
\text { saflarında yer alıyor" }\end{array}$ \\
\hline
\end{tabular}




\begin{tabular}{|c|c|c|c|c|c|}
\hline 13 & $\begin{array}{c}11 \text { Ekim } \\
\text { 2019, } \\
\text { Türkçe }\end{array}$ & $\begin{array}{c}\text { Büyükelçi Dr. İsmail } \\
\text { Hakkı Musa, BFM TV } \\
\text { kanalında yayınlanan } \\
\text { mülakatında Barış Pınarı } \\
\text { Harekâtı hakkında bilgi } \\
\text { vermiştir. } \\
\text { \#BarışPınarıHarekâtı }\end{array}$ & 13 & $\begin{array}{c}11 \text { Ekim } \\
\text { 2019, } \\
\text { Fransizca }\end{array}$ & $\begin{array}{c}\text { TRT Français } \\
\text { @TRTFrancais } \\
\text { Ankara: "Barış Pınarı } \\
\text { Operasyonu bölgenin } \\
\text { demografik yönünü } \\
\text { değiştirmekle ilgili değil" }\end{array}$ \\
\hline 14 & $\begin{array}{c}11 \text { Ekim } \\
\text { 2019, } \\
\text { Fransizca }\end{array}$ & $\begin{array}{c}\text { Büyükelçi Dr. İsmail } \\
\text { Hakkı Musa, BFM TV } \\
\text { kanalında yayınlanan } \\
\text { mülakatında Barış Pınarı } \\
\text { Harekâtı hakkında bilgi } \\
\text { vermiştir. } \\
\text { \#BarışPınarıHarekâtı }\end{array}$ & 14 & $\begin{array}{c}11 \text { Ekim } \\
\text { 2019, } \\
\text { Fransizca }\end{array}$ & $\begin{array}{c}\text { Turkish MFA French } \\
\text { @MFATurkeyFrench } \\
\text { Barış Pınarı Operasyonu } \\
\text { ile ilgili uluslararası } \\
\text { toplumdan yapılan bazı } \\
\text { yorumlar hakkında basın } \\
\text { açıklaması }\end{array}$ \\
\hline 15 & $\begin{array}{c}11 \text { Ekim } \\
2019, \\
\text { İngilizce }\end{array}$ & $\begin{array}{c}\text { Büyükelçi Dr. İsmail } \\
\text { Hakkı Musa, BFM TV } \\
\text { kanalında yayınlanan } \\
\text { mülakatında Barış Pınarı } \\
\text { Harekâtı hakkında bilgi } \\
\text { vermiştir. } \\
\text { \#BarışPınarıHarekâtı }\end{array}$ & 15 & $\begin{array}{l}11 \text { Ekim } \\
\text { 2019, } \\
\text { İngilizce }\end{array}$ & $\begin{array}{c}\text { Mevlüt Çavuşoğlu } \\
\text { @MevlutCavusoglu } \\
\text { (T.C. Dışişleri Bakanı) } \\
\text { Bugünkü röportajım } \\
\text { @NYTimes } \\
\text { OperasyonPeaceSpring: } \\
\text { Neden Türkiye Suriye İle } \\
\text { Mücadeleye Katıldı? }\end{array}$ \\
\hline 16 & $\begin{array}{c}11 \text { Ekim } \\
\text { 2019, } \\
\text { Türkçe }\end{array}$ & $\begin{array}{c}\text { Büyükelçi Dr. İsmail } \\
\text { Hakkı Musa bugün } \\
\text { Cnews TV kanalında } \\
\text { canlı yayına katılarak } \\
\text { \#BarışPınarıHarekâtı } \\
\text { hakkında bilgi vermiştir. } \\
\text { Mülakat aşağıda sunulan } \\
\text { bağlantının 20. } \\
\text { dakikasından itibaren } \\
\text { izlenebilir. }\end{array}$ & 16 & $\begin{array}{c}12 \text { Ekim } \\
\text { 2019, } \\
\text { Fransizca }\end{array}$ & $\begin{array}{c}\text { Turkish MFA French } \\
\text { @MFATurkeyFrench } \\
\text { Dişişleri Bakanı Mevlüt } \\
\text { Çavuşoğlu'nun "Türkiye } \\
\text { Suriye'de mücadeleye } \\
\text { neden öncülük etti? } 11 \\
\text { Ekim 2019'da New York } \\
\text { Times gazetesinde } \\
\text { yayınlandı }\end{array}$ \\
\hline 17 & $\begin{array}{c}11 \text { Ekim } \\
\text { 2019, } \\
\text { Fransizca }\end{array}$ & $\begin{array}{c}\text { Büyükelçi Dr. İsmail } \\
\text { Hakkı Musa bugün } \\
\text { Cnews TV kanalında } \\
\text { canlı yayına katılarak } \\
\text { \#BarışPınarıHarekâtı } \\
\text { hakkında bilgi vermiştir. } \\
\text { Mülakat aşağıda sunulan } \\
\text { bağlantının 20. } \\
\text { dakikasından itibaren } \\
\text { izlenebilir. }\end{array}$ & 17 & $\begin{array}{c}12 \text { Ekim } \\
\text { 2019, } \\
\text { Fransizca }\end{array}$ & $\begin{array}{c}\text { Turkish MFA French } \\
\text { @MFATurkeyFrench } \\
\text { Dışişleri Bakanlığı } \\
\text { Sözcüsü Hami Aksoy'un, } \\
\text { Barış Pınarı } \\
\text { Operasyonunda } \\
\text { Allkonulan DAEŞ } \\
\text { Üyeleri ve Aileleri } \\
\text { Konusundaki Görüşleri }\end{array}$ \\
\hline 18 & $\begin{array}{c}11 \text { Ekim } \\
2019, \\
\text { İngilizce }\end{array}$ & $\begin{array}{l}\text { Büyükelçi Dr. İsmail } \\
\text { Hakkı Musa bugün } \\
\text { Cnews TV kanalında } \\
\text { canlı yayına katılarak } \\
\text { \#BarışPınarıHarekâtı } \\
\text { hakkında bilgi vermiştir. }\end{array}$ & 18 & $\begin{array}{c}13 \text { Ekim } \\
\text { 2019, } \\
\text { Fransizca }\end{array}$ & $\begin{array}{l}\text { Turkish MFA French } \\
\text { @MFATurkeyFrench } \\
\text { Yurtdışında şiddetli } \\
\text { saldırı, gösteri ve PKK } \\
\text { eylemlerinin sayısının }\end{array}$ \\
\hline
\end{tabular}


Kamu Diplomasisinde Dijital Dönüşüm: Büyükelçilerin Twitter Üzerinden Gerçekleştirdikleri Dijital Diplomasi Faaliyetlerinin İncelenmesi Mesut İris, Tansu Akdemir

\begin{tabular}{|c|c|c|c|c|c|}
\hline & & $\begin{array}{l}\text { Mülakat aşağıda sunulan } \\
\text { bağlantının } 20 . \\
\text { dakikasından itibaren } \\
\text { izlenebilir. }\end{array}$ & & & $\begin{array}{c}\text { artması konusunda basın } \\
\text { açılaması }\end{array}$ \\
\hline 19 & $\begin{array}{l}12 \text { Ekim } \\
\text { 2019, } \\
\text { Türkçe }\end{array}$ & $\begin{array}{c}\text { Büyükelçi Dr. İsmail } \\
\text { Hakkı Musa, France } 24 \\
\text { televizyon kanalında } \\
\text { yayınlanan mülakatında } \\
\text { \#BarışPınarıHarekâtı } \\
\text { hakkında bilgi vermiştir. }\end{array}$ & 19 & $\begin{array}{c}15 \text { Ekim } \\
\text { 2019, } \\
\text { Fransizca }\end{array}$ & $\begin{array}{l}\text { Turkish MFA French } \\
\text { @MFATurkeyFrench } \\
\text { AB Dışişleri Konseyi } \\
\text { tarafından kabul edilen } \\
\text { sonuçlar üzerine basın } \\
\text { açıklaması }\end{array}$ \\
\hline 20 & $\begin{array}{c}12 \text { Ekim } \\
\text { 2019, } \\
\text { Fransizca }\end{array}$ & $\begin{array}{c}\text { Büyükelçi Dr. İsmail } \\
\text { Hakkı Musa, France } 24 \\
\text { televizyon kanalında } \\
\text { yayınlanan mülakatında } \\
\text { \#BarışPınarıHarekâtı } \\
\text { hakkında bilgi vermiştir }\end{array}$ & 20 & $\begin{array}{c}15 \text { Ekim } \\
\text { 2019, } \\
\text { Fransizca }\end{array}$ & $\begin{array}{c}\text { TRT Français } \\
\text { @TRTFrancais } \\
\text { "Türkiye, uluslararası } \\
\text { hukuka göre Barış Pınarı } \\
\text { Operasyonuna liderlik } \\
\text { ediyor" }\end{array}$ \\
\hline 21 & $\begin{array}{l}12 \text { Ekim } \\
\text { 2019, } \\
\text { İngilizce }\end{array}$ & $\begin{array}{c}\text { Büyükelçi Dr. İsmail } \\
\text { Hakkı Musa, France } 24 \\
\text { televizyon kanalında } \\
\text { yayınlanan mülakatında } \\
\text { \#BarışPınarıHarekâtı } \\
\text { hakkında bilgi vermiştir }\end{array}$ & 21 & $\begin{array}{l}15 \text { Ekim } \\
\text { 2019, } \\
\text { Fransizca }\end{array}$ & $\begin{array}{c}\text { ANADOLU AGENCY } \\
\text { (FR) } \\
\text { @aa_french } \\
\text { Erdoğan, Macron ile } \\
\text { röportajında, Barış Pınarı } \\
\text { Operasyonunun bölgesel } \\
\text { ve küresel barış ve } \\
\text { istikrara katkı } \\
\text { sağlayacağını savundu. }\end{array}$ \\
\hline 22 & $\begin{array}{l}14 \text { Ekim } \\
\text { 2019, } \\
\text { Türkçe }\end{array}$ & $\begin{array}{c}\text { Büyükelçi Dr. İsmail } \\
\text { Hakkı Musa, bu sabah } \\
\text { RMC kanalında Bourdin } \\
\text { Direct programına } \\
\text { katılarak Barış Pınarı } \\
\text { Harekâtı hakkında bilgi } \\
\text { vermiştir. } \\
\text { \#BarışPınarıHarekâtı }\end{array}$ & 22 & $\begin{array}{l}16 \text { Ekim } \\
2019, \\
\text { Fransizca }\end{array}$ & $\begin{array}{l}\text { Turkish MFA French } \\
\text { @MFATurkeyFrench } \\
\text { Yurtdışında PKK'nın } \\
\text { artan saldırı, gösteri ve } \\
\text { şiddet içeren eylemleri } \\
\text { hakkında basın } \\
\text { açıklaması }\end{array}$ \\
\hline 23 & $\begin{array}{l}14 \text { Ekim } \\
\text { 2019, } \\
\text { Fransizca }\end{array}$ & $\begin{array}{c}\text { Büyükelçi Dr. İsmail } \\
\text { Hakkı Musa, bu sabah } \\
\text { RMC kanalında Bourdin } \\
\text { Direct programına } \\
\text { katılarak Barış Pınarı } \\
\text { Harekâtı hakkında bilgi } \\
\text { vermiştir. } \\
\text { \#BarışPınarıHarekâtı }\end{array}$ & 23 & $\begin{array}{l}17 \text { Ekim } \\
\text { 2019, } \\
\text { Fransizca }\end{array}$ & $\begin{array}{c}\text { TRT Français } \\
\text { @TRTFrancais } \\
\text { Kalın: "Türkiye'nin } \\
\text { istediği güvenlik bölgesi } \\
\text { DAEŞ'le mücadeleyi } \\
\text { etkilemeyecek" }\end{array}$ \\
\hline 24 & $\begin{array}{l}14 \text { Ekim } \\
\text { 2019, } \\
\text { İngilizce }\end{array}$ & $\begin{array}{c}\text { Büyükelçi Dr. İsmail } \\
\text { Hakkı Musa, bu sabah } \\
\text { RMC kanalında Bourdin } \\
\text { Direct programına } \\
\text { katılarak Barış Pınarı } \\
\text { Harekâtı hakkında bilgi }\end{array}$ & 24 & $\begin{array}{l}17 \text { Ekim } \\
\text { 2019, Türkçe }\end{array}$ & $\begin{array}{c}\text { Mevlüt Çavuşoğlu } \\
\text { @MevlutCavusoglu } \\
\text { (T.C. Dişişleri Bakanı) } \\
\text { Sayın } \\
\text { Cumhurbaşkanımız } \\
\text { @RTErdogan 'ın } \\
\text { liderliğinde }\end{array}$ \\
\hline
\end{tabular}




\begin{tabular}{|c|c|c|c|c|c|}
\hline & & $\begin{array}{c}\text { vermiştir. } \\
\text { \#BarışPınarıHarekâtı }\end{array}$ & & & (görsel paylaşımı) \\
\hline 25 & $\begin{array}{l}14 \text { Ekim } \\
\text { 2019, } \\
\text { Türkçe }\end{array}$ & $\begin{array}{c}\text { Büyükelçi Dr. İsmail } \\
\text { Hakkı Musa, bu sabah } \\
\text { LCI kanalında canlı } \\
\text { yayına katılarak Barış } \\
\text { Pınarı Harekâtı hakkında } \\
\text { bilgi vermiştir. } \\
\text { \#BarışınarıHarekâtı }\end{array}$ & 25 & $\begin{array}{l}18 \text { Ekim } \\
\text { 2019, } \\
\text { Fransizca }\end{array}$ & $\begin{array}{c}\text { Turkish MFA French } \\
\text { @MFATurkeyFrench } \\
\text { Dışişleri Bakanlığı } \\
\text { Sözcüsü Hami Aksoy'un } \\
\text { Barış Pınarı Operasyon } \\
\text { Sırasında Türkiye'nin } \\
\text { Kimyasal Silah Kullanım } \\
\text { İddiası Üzerine Görüşleri }\end{array}$ \\
\hline 26 & $\begin{array}{c}14 \text { Ekim } \\
\text { 2019, } \\
\text { Fransizca }\end{array}$ & $\begin{array}{c}\text { Büyükelçi Dr. İsmail } \\
\text { Hakkı Musa, bu sabah } \\
\text { LCI kanalında canlı } \\
\text { yayına katılarak Barış } \\
\text { Pınarı Harekâtı hakkında } \\
\text { bilgi vermiştir. } \\
\text { \#BarışPınarıHarekâtı }\end{array}$ & 26 & $\begin{array}{c}19 \text { Ekim } \\
\text { 2019, Türkçe } \\
\text { ve İngilizce }\end{array}$ & $\begin{array}{c}\text { Mevlüt Çavuşoğlu } \\
\text { @MevlutCavusoglu } \\
\text { (T.C. Dişişleri Bakanı) } \\
\text { Yerinde tespit! } \\
\text { Well said! } \\
\text { (video paylaşımı) }\end{array}$ \\
\hline 27 & $\begin{array}{c}14 \text { Ekim } \\
2019, \\
\text { Ingilizce }\end{array}$ & $\begin{array}{c}\text { Büyükelçi Dr. İsmail } \\
\text { Hakkı Musa, bu sabah } \\
\text { LCI kanalında canlı } \\
\text { yayına katılarak Barış } \\
\text { Pınarı Harekâtı hakkında } \\
\text { bilgi vermiştir. } \\
\text { \#BarışPınarıHarekâtı } \\
\end{array}$ & 27 & $\begin{array}{l}20 \text { Ekim } \\
\text { 2019, } \\
\text { Fransizca }\end{array}$ & $\begin{array}{c}\text { ANADOLU AGENCY } \\
\text { (FR) } \\
\text { @aa_french } \\
\text { Suriye'deki Türk- } \\
\text { Amerikan anlaşması: } \\
\text { PKK / YPG anlaşmanın } \\
\text { ihlallerini çoğalttı. }\end{array}$ \\
\hline 28 & $\begin{array}{l}14 \text { Ekim } \\
\text { 2019, } \\
\text { Türkçe }\end{array}$ & $\begin{array}{c}\text { Büyükelçi Dr. İsmail } \\
\text { Hakkı Musa, bu sabah } \\
\text { BFMTV kanalında canlı } \\
\text { yayına katılarak Barış } \\
\text { Pınarı arekatı hakkında } \\
\text { bilgi vermiştir. } \\
\text { \#BarışPınarıHarekâtı }\end{array}$ & 28 & $\begin{array}{l}20 \text { Ekim } \\
\text { 2019, } \\
\text { Fransizca }\end{array}$ & $\begin{array}{c}\text { Turkish MFA French } \\
\text { @MFATurkeyFrench } \\
\text { Uluslararası Af Örgütü } \\
\text { Barış Pınarı } \\
\text { Operasyonuna İlişkin } \\
\text { Raporda Yer Alan } \\
\text { İddialara İlişkin Basın } \\
\text { Açıklaması } \\
\end{array}$ \\
\hline 29 & $\begin{array}{c}14 \text { Ekim } \\
\text { 2019, } \\
\text { Fransizca }\end{array}$ & $\begin{array}{c}\text { Büyükelçi Dr. İsmail } \\
\text { Hakkı Musa, bu sabah } \\
\text { BFMTV kanalında canlı } \\
\text { yayına katılarak Barış } \\
\text { Pınarı arekatı hakkında } \\
\text { bilgi vermiştir. } \\
\text { \#BarışPınarıHarekâtı }\end{array}$ & 29 & $\begin{array}{l}20 \text { Ekim } \\
\text { 2019, } \\
\text { Fransizca }\end{array}$ & $\begin{array}{c}\text { TRT Français } \\
\text { @TRTFrancais } \\
\text { Çavuşoğlu: "Barış Pınarı } \\
\text { Operasyonu ile önemli } \\
\text { bir plan yaptık" }\end{array}$ \\
\hline 30 & $\begin{array}{c}14 \text { Ekim } \\
2019, \\
\text { Ingilizce }\end{array}$ & $\begin{array}{c}\text { Büyükelçi Dr. İsmail } \\
\text { Hakkı Musa, bu sabah } \\
\text { BFMTV kanalında canlı } \\
\text { yayına katılarak Barış } \\
\text { Pınarı Harekâtı hakkında } \\
\text { bilgi vermiştir. } \\
\text { \#BarışınarıHarekâtı } \\
\end{array}$ & 30 & $\begin{array}{l}22 \text { Ekim } \\
\text { 2019, Türkçe }\end{array}$ & $\begin{array}{l}\text { T.C. Cumhurbaşkanlığı } \\
\text { @tcbestepe } \\
\text { Türkiye-Rusya } \\
\text { Federasyonu Arasında } \\
\text { Mutabakat Muhtırası }\end{array}$ \\
\hline
\end{tabular}


Kamu Diplomasisinde Dijital Dönüşüm: Büyükelçilerin Twitter Üzerinden Gerçekleştirdikleri Dijital Diplomasi Faaliyetlerinin İncelenmesi Mesut İris, Tansu Akdemir

\begin{tabular}{|c|c|c|c|c|c|}
\hline 31 & $\begin{array}{l}15 \text { Ekim } \\
2019, \\
\text { Fransizca }\end{array}$ & $\begin{array}{c}\text { Terör örgütü PYD / YPG, } \\
\text { teröristleri DAEŞ'ten } \\
\text { serbest bıraktı. Le } \\
\text { Parisien gazetesindeki } \\
\text { makaleye bakın: } \\
\text { (haber sitesi paylaşımı) }\end{array}$ & 31 & $\begin{array}{l}22 \text { Ekim } \\
\text { 2019, } \\
\text { Fransizca }\end{array}$ & $\begin{array}{c}\text { TRT Français } \\
\text { @TRTFrancais } \\
\text { Avrupa ülkelerinin kabul } \\
\text { etmeyi reddettiği, YPG / } \\
\text { PKK ile olan bağları, } \\
\text { sokaklarında "somut" }\end{array}$ \\
\hline 32 & $\begin{array}{l}14 \text { Ekim } \\
2019, \\
\text { Türkçe }\end{array}$ & $\begin{array}{l}\text { Büyükelçi Dr. İsmail } \\
\text { Hakkı Musa, bu akşam } \\
\text { France Info kanalında } \\
\text { Barış Pınarı Harekâtı } \\
\text { hakkında soruları } \\
\text { yanıtlamıştır. } \\
\text { \#BarışPınarıHarekâtı }\end{array}$ & 32 & $\begin{array}{l}23 \text { Ekim } \\
\text { 2019, } \\
\text { Fransizca }\end{array}$ & $\begin{array}{c}\text { ANADOLU AGENCY } \\
\text { (FR) } \\
\text { @aa_french } \\
\text { Çavuşoğlu: Suriye'deki } \\
\text { Türk operasyonları } \\
\text { bölgenin dinamiklerini } \\
\text { tamamen değiştirdi }\end{array}$ \\
\hline 33 & $\begin{array}{l}14 \text { Ekim } \\
2019, \\
\text { Fransizca }\end{array}$ & $\begin{array}{l}\text { Büyükelçi Dr. İsmail } \\
\text { Hakkı Musa, bu akşam } \\
\text { France Info kanalında } \\
\text { Barış Pınarı Harekâtı } \\
\text { hakkında soruları } \\
\text { yanıtlamıştır. } \\
\text { \#BarışPınarıHarekâtı }\end{array}$ & 33 & $\begin{array}{l}23 \text { Ekim } \\
\text { 2019, } \\
\text { Fransizca }\end{array}$ & $\begin{array}{c}\text { TRT Français } \\
\text { @TRTFrancais } \\
\text { Erdoğan-Putin'in } \\
\text { Rusya'daki röportajı } \\
\text { Suriye ile ilgili tarihi bir } \\
\text { anlaşmaya varıyor }\end{array}$ \\
\hline 34 & $\begin{array}{l}14 \text { Ekim } \\
2019, \\
\text { İngilizce }\end{array}$ & $\begin{array}{l}\text { Büyükelçi Dr. İsmail } \\
\text { Hakkı Musa, bu akşam } \\
\text { France Info kanalında } \\
\text { Barış Pınarı Harekâtı } \\
\text { hakkında soruları } \\
\text { yanıtlamıştır. } \\
\text { \#BarışPınarıHarekâtı }\end{array}$ & 34 & $\begin{array}{c}24 \text { Ekim } \\
\text { 2019, Türkçe }\end{array}$ & $\begin{array}{c}\text { T.C. Dışişleri Bakanlığı } \\
\text { @TC_Disisleri } \\
\text { Avrupa } \\
\text { Parlamentosu'nda Kabul } \\
\text { Edilen Barış Pınarı } \\
\text { Harekâtı Konulu Karar } \\
\text { Hk. }\end{array}$ \\
\hline 35 & $\begin{array}{l}16 \text { Ekim } \\
2019, \\
\text { Fransizca }\end{array}$ & $\begin{array}{c}\text { Bugün } \\
\text { \#ConsDefenseSenate } \\
\text { üyelerini, terör örgütü } \\
\text { PYD / YPG'nin gerçek } \\
\text { doğası ve aynı zamanda } \\
\text { suçlarının gerçek doğası } \\
\text { hakkında uluslararası } \\
\text { hukuk yasalarının } \\
\text { amaçları ve yasal } \\
\text { dayanağı hakkında } \\
\text { bilgilendirdik. } \\
(1 / 3)\end{array}$ & 35 & $\begin{array}{c}24 \text { Ekim } \\
\text { 2019, } \\
\text { Fransizca }\end{array}$ & $\begin{array}{c}\text { Turkish MFA French } \\
\text { @MFATurkeyFrench } \\
\text { Avrupa } \\
\text { Parlamentosu'nda Kabul } \\
\text { Edilen Barış Pınarı } \\
\text { Harekâtı Konulu Karar } \\
\text { Hk. }\end{array}$ \\
\hline 36 & $\begin{array}{l}16 \text { Ekim } \\
\text { 2019, } \\
\text { Fransizca }\end{array}$ & $\begin{array}{c}\text { Senato'da, diğer şeylerin } \\
\text { yanı sıra şunları } \\
\text { vurguladık: Amacımız } \\
\text { teröristleri yetersiz } \\
\text { tutmak ve sınırlarımızı } \\
\text { güvenceye almak, } \\
\text { operasyon belirli bir etnik } \\
\text { nüfusu hedeflememek ve } \\
\text { demografik yapıyı }\end{array}$ & 36 & $\begin{array}{l}27 \text { Ekim } \\
\text { 2019, Türkçe }\end{array}$ & $\begin{array}{c}\text { T.C. Dişişleri Bakanlığı } \\
\text { @TC_Disisleri } \\
\text { Dişişleri Bakanlığı } \\
\text { Sözcüsü Hami Aksoy'un } \\
\text { Terör Örgütü DEAŞ } \\
\text { Elebaşı Ebubekir El } \\
\text { Bağdadi'nin Öldürülmesi } \\
\text { Hakkındaki Soruya } \\
\text { Cevabı } \\
\end{array}$ \\
\hline
\end{tabular}




\begin{tabular}{|c|c|c|c|c|c|}
\hline & & $\begin{array}{l}\text { değiştirmek niyetinde } \\
\text { değildi. }(2 / 3)\end{array}$ & & & \\
\hline 37 & $\begin{array}{l}16 \text { Ekim } \\
\text { 2019, } \\
\text { Fransizca }\end{array}$ & $\begin{array}{l}\text { \#SeDefenseSenate Şunu } \\
\text { vurguladık: } \\
\text {-DAEŞ ile mücadele, terör } \\
\text { örgütlerine dış kaynak } \\
\text { kullanılamaz, } \\
\text {-Ülkemiz, menşe ülkeleri } \\
\text { ile nihai bir çözüm bulana } \\
\text { kadar yabancı savaşılları } \\
\text { kontrol altına almaya } \\
\text { hazırdır (3/3) }\end{array}$ & 37 & $\begin{array}{l}28 \text { Ekim } \\
\text { 2019, } \\
\text { Fransizca }\end{array}$ & $\begin{array}{c}\text { Turkish MFA French } \\
\text { @MFATurkeyFrench } \\
\text { Dışişleri Bakanlığı } \\
\text { Sözcüsü Hami Aksoy'un } \\
\text { Terör Örgütü DEAŞ } \\
\text { Elebaşı Ebubekir El } \\
\text { Bağdadi'nin Öldürülmesi } \\
\text { Hakkındaki Soruya } \\
\text { Cevabı }\end{array}$ \\
\hline 38 & $\begin{array}{l}\text { 16 Ekim } \\
\text { 2019, } \\
\text { Fransizca }\end{array}$ & $\begin{array}{l}\text { Cumhurbaşkanı Recep } \\
\text { Tayyip Erdoğan: “Suriye } \\
\text { halkına karşı } \\
\text { savaşmıyoruz, ancak } \\
\text { Suriye halkıyla birlikte, } \\
\text { baskıcılarla ve } \\
\text { teröristlerle savaşıyoruz. " } \\
\text { (görsel paylaşım) }\end{array}$ & 38 & $\begin{array}{c}28 \text { Ekim } \\
\text { 2019, } \\
\text { Fransizca }\end{array}$ & $\begin{array}{c}\text { TRT Français } \\
\text { @TRTFrancais } \\
\text { Altun: "Türkiye arkadaş } \\
\text { ve müttefikleriyle terörle } \\
\text { mücadeleye devam } \\
\text { ediyor" }\end{array}$ \\
\hline 39 & $\begin{array}{l}18 \text { Ekim } \\
\text { 2019, } \\
\text { Fransizca }\end{array}$ & $\begin{array}{c}\text { Türk-Amerikan ortak } \\
\text { bildirisi: Güvenli bölge, } \\
\text { Türk kuvvetlerinin } \\
\text { kontrolü altında olacak. } \\
\text { \#OperationSourcedePaix }\end{array}$ & 39 & $\begin{array}{l}30 \text { Ekim } \\
\text { 2019, } \\
\text { Fransizca }\end{array}$ & $\begin{array}{l}\text { Turkish MFA French } \\
\text { @MFATurkeyFrench } \\
\text { ABD'nin Türkiye'ye } \\
\text { Karşı Yaptırımlar } \\
\text { Yapmasını Sağlayan } \\
\text { Temsilciler Meclisi'nin } \\
\text { Kararı ile ilgili }\end{array}$ \\
\hline 40 & $\begin{array}{l}21 \text { Ekim } \\
\text { 2019, } \\
\text { Fransizca }\end{array}$ & $\begin{array}{l}\text { \#OpérationSourcedePaix } \\
\text { (haber sitesi paylaşımı) }\end{array}$ & 40 & $\begin{array}{l}30 \text { Ekim } \\
\text { 2019, } \\
\text { Fransizca }\end{array}$ & $\begin{array}{c}\text { ANADOLU AGENCY } \\
\text { (FR) } \\
\text { @aa_french } \\
\text { \#Syria'da, \#Türkiye, } \\
\text { kardeşlerini düşünen tek } \\
\text { ülkedir \# petrol değil } \\
\text { (Bölüm1) } \\
\text { Cumhurbaşkanı } \\
\text { \#Erdogan, Cumhuriyet } \\
\text { Bayramı töreninde bir } \\
\text { konuşma yaptı. }\end{array}$ \\
\hline 41 & $\begin{array}{l}21 \text { Ekim } \\
\text { 2019, } \\
\text { Fransizca }\end{array}$ & $\begin{array}{c}\text { Türkiye-Amerika Birleşik } \\
\text { Devletleri Kuzeydoğu } \\
\text { Suriye Hakkında Ortak } \\
\text { Açıklama } \\
\text { \# OpérationSourcedePaix } \\
\text { (görsel ile açılama) }\end{array}$ & 41 & $\begin{array}{c}30 \text { Ekim } \\
\text { 2019, } \\
\text { Fransizca }\end{array}$ & $\begin{array}{c}\text { ANADOLU AGENCY } \\
\text { (FR) } \\
\text { @aa_french } \\
\text { \#Syria'da, \#Türkiye, } \\
\text { kardeşlerini düşünen tek } \\
\text { ülkedir \# petrol değil } \\
\text { (Bölüm2) }\end{array}$ \\
\hline
\end{tabular}


Kamu Diplomasisinde Dijital Dönüşüm: Büyükelçilerin Twitter Üzerinden Gerçekleştirdikleri Dijital Diplomasi Faaliyetlerinin İncelenmesi Mesut İris, Tansu Akdemir

\begin{tabular}{|c|c|c|c|c|c|}
\hline & & & & & $\begin{array}{l}\text { Cumhurbaşkanı } \\
\text { \#Erdogan, Cumhuriyet } \\
\text { Bayramı töreninde bir } \\
\text { konuşma yaptı. }\end{array}$ \\
\hline \multirow[t]{5}{*}{42} & $\begin{array}{c}22 \text { Ekim } \\
\text { 2019, } \\
\text { Fransizca }\end{array}$ & $\begin{array}{c}\text { \#OpérationSourcedePaix } \\
\text { (haber sitesi paylaşımı) }\end{array}$ & 42 & $\begin{array}{l}30 \text { Ekim } \\
\text { 2019, } \\
\text { Fransizca }\end{array}$ & $\begin{array}{c}\text { ANADOLU AGENCY } \\
\text { (FR) } \\
\text { @aa_french } \\
\text { \# Çavuşoğlu, Temsilciler } \\
\text { Meclisi'nin \#Türkiye } \\
\text { aleyhindeki metnin } \\
\text { kabulüne tepki gösteriyor }\end{array}$ \\
\hline & & & 43 & $\begin{array}{l}31 \text { Ekim } \\
\text { 2019, } \\
\text { Fransizca }\end{array}$ & $\begin{array}{c}\text { İsmail Hakkı Musa } \\
\text { @ihakkimusa } \\
\text { T.C. Paris Büyükelçisi } \\
\text { \#PeaceSource } \\
\text { Operasyonu, Türkiye'yi } \\
\text { güvenlik hakkından ve } \\
\text { bölgeyi istikrara } \\
\text { kavuşturma arzusundan } \\
\text { feragat etmeye zorlayan } \\
\text { temelsiz eleştirilere, } \\
\text { teşvik edici ifadelere ve } \\
\text { verimsiz siyasi kararlara } \\
\text { yol açtı. }{ }^{1} / 4 \\
\end{array}$ \\
\hline & & & 44 & $\begin{array}{l}31 \text { Ekim } \\
\text { 2019, } \\
\text { Fransizca }\end{array}$ & $\begin{array}{c}\text { İsmail Hakkı Musa } \\
\text { @ihakkimusa } \\
\text { T.C. Paris Büyükelçisi } \\
\text { \#PeaceSourceOperation } \\
\text { "Kürtleri" değil, PYD / } \\
\text { YPG / PKK ve DAESH } \\
\text { terör örgütlerini hedef } \\
\text { alıyor. 2/4 }\end{array}$ \\
\hline & & & 45 & $\begin{array}{l}31 \text { Ekim } \\
\text { 2019, } \\
\text { Fransizca }\end{array}$ & $\begin{array}{c}\text { İsmail Hakkı Musa } \\
\text { @ihakkimusa } \\
\text { T.C. Paris Büyükelçisi } \\
\text { Terörist örgütlerle } \\
\text { mücadele, başka bir } \\
\text { terörist örgüte emanet } \\
\text { edilemez. } \\
\text { 3/4 }\end{array}$ \\
\hline & & & 46 & $\begin{array}{l}31 \text { Ekim } \\
\text { 2019, } \\
\text { Fransizca }\end{array}$ & $\begin{array}{c}\text { İsmail Hakkı Musa } \\
\text { @ihakkimusa } \\
\text { T.C. Paris Büyükelçisi } \\
\text { Türkiye'nin } \\
\text { mücadelesinin yalnızca } \\
\text { çıkarlarına hizmet } \\
\end{array}$ \\
\hline
\end{tabular}




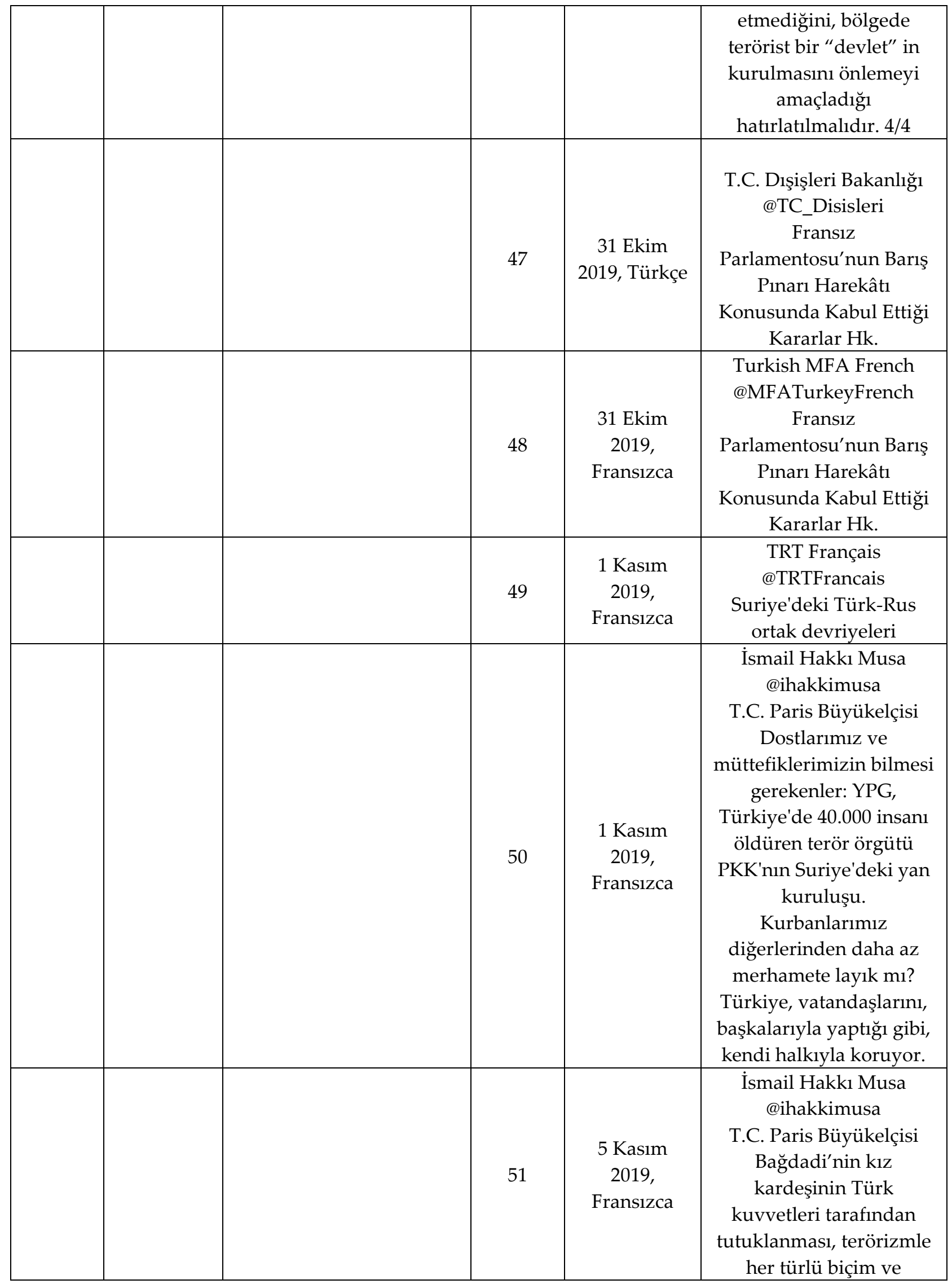


Kamu Diplomasisinde Dijital Dönüşüm:

\begin{tabular}{|c|c|c|c|c|}
\hline & & & $\begin{array}{c}\text { tezahürle mücadele etme } \\
\text { kararlılı̆ımızın yeni bir } \\
\text { kanıtı. \#DAECH \#PKK } \\
\text { \#YPG }\end{array}$ \\
\hline & & & & $\begin{array}{c}\text { Ismail Hakk1 Musa } \\
\text { @ihakkimusa } \\
\text { T.C. Paris Büyükelçisi } \\
\text { DAECH ile mücadelede } \\
\text { verdiğimiz } \\
\text { taahhüdümüzden } \\
\text { şüphelenenler için, } \\
\text { envanter: } \\
\text { - 2017 yılında "Fırat } \\
\text { Kalkant" ve 2018'de } \\
\text { "Rameau d'Olivier" } \\
\text { Operasyonu sirasında } \\
\text { Türk Ordusu tarafindan } \\
\text { nötralize edilen 4.000'den } \\
\text { fazla terörist. }\end{array}$ \\
\hline
\end{tabular}

Türkiye Paris Büyükelçiliği Twitter hesabının harekât ile ilgili paylaşımları yukarıda görüleceği üzere sıralanmıştır. Büyükelçilik Twitter hesabı Nisan 2010 yılından beri faaliyet gösterirken, hesabın yaklaşık 6 bin takipçisi bulunmaktadır. Büyükelçiliğin harekât ile ilgili toplam 42 Tweeti, 52 Retweeti vardır. Tweetlerin içeriğine bakıldığı zaman, Harekâtı n gerçekleştirilme nedenlerini, gerekliliğini ve meşruluğunu açıklama odaklı olduğu görülmektedir. Konu ile ilgili büyükelçilik faaliyetlerinin yanı sıra büyükelçinin de şahsi olarak gerçekleştirdiği kamu diplomasisi faaliyetlerine yer verilmiştir. Ayrıca haber paylaşımlarının da yapıldığı görülmektedir.

Retweetlere bakıldığı zaman, Dışişleri Bakanlığı faaliyetlerinin takip edildiği anlaşılmaktadır. Ayrıca Fransa odaklı televizyon kanallarının paylaşımlarına da yer verildiği görülmektedir. Anadolo Ajansı, TRT gibi kamu kurumlarının aktardığı haberlerin retweet'lendiği görülmektedir.

Operasyonun nedenleri ve meşruluğu üzerine yapılan paylaşımlarda görsel unsurların kullanılması (adım adım operasyonun nedenlerinin görsel bir şekilde anlatılması) ve somut haberlerle paylaşımların desteklenmesi dijital diplomasi faaliyetlerine iyi birer örnek olarak gösterilebilir. Bunun yanısıra Büyükelçilik hesabı takipçi sayısının niceliği ve niteliği de önem arz etmektedir. 
Tablo 3. Türkiye Berlin Büyükelçiliği Büyükelçilik resmi Twitter hesabı paylaşımları*

Not: Büyükelçi Ali Kemal AYDIN'ın şahsi twitter hesabı bulunmamaktadır.

\begin{tabular}{|c|c|c|c|c|c|}
\hline & & $\begin{array}{r}\text { Türki } \\
\text { Büyükelc } \\
\\
\text { Hesap } \\
\text { weetler: 6.932 Takip }\end{array}$ & $\begin{array}{l}\text { e Berlin B } \\
\text { lik Resmi } \\
\text { T.C. Berl } \\
\text { @TC_Ber } \\
\text { çllsş Taril } \\
\text { dilen: } 309\end{array}$ & $\begin{array}{l}\text { üyükelçiliği } \\
\text { Twitter Hesab } \\
\text { n BE } \\
\text { inBE } \\
\text { i: Aralık } 2011 \\
\text { Takipçiler: } 6.5\end{array}$ & Beğeni: 240 \\
\hline $\begin{array}{c}\text { Harekât } \\
\text { ile ilgili } \\
\text { Atılan } \\
\text { Tweet } \\
\text { Sayısı } \\
\end{array}$ & $\begin{array}{l}\text { Atılan } \\
\text { Tweetlerin } \\
\text { Tarihi ve } \\
\text { Lisanı }\end{array}$ & $\begin{array}{c}\text { Atılan Tweetlerin } \\
\text { İçeriği }\end{array}$ & $\begin{array}{c}\text { Harekât } \\
\text { ile ilgili } \\
\text { Retweet } \\
\text { Sayısı }\end{array}$ & $\begin{array}{c}\text { Atılan } \\
\text { Retweetlerin } \\
\text { Tarihi ve } \\
\text { Lisanı }\end{array}$ & $\begin{array}{c}\text { Atılan } \\
\text { Retweetlerin } \\
\text { İçeriği }\end{array}$ \\
\hline 1 & $\begin{array}{l}\text { 9 Ekim } \\
\text { 2019, } \\
\text { Almanca, } \\
\text { (paylaşılan } \\
\text { haber } \\
\text { içeriği } \\
\text { İngilizce) }\end{array}$ & $\begin{array}{l}\text { Türkiye, Trump’ın } \\
\text { Suriye kararıyla } \\
\text { ilgili - DAEŞ'e karşı } \\
\text { liderlik edebiliriz. } \\
\text { (İletişim Başkanı } \\
\text { Fahrettin Altun'un } \\
\text { Washington Post'ta } \\
\text { yayımlanan } \\
\text { makalesi. } \\
\text { “Dünya } \\
\text { Türkiye'nin } \\
\text { Kuzeydoğu Suriye } \\
\text { planını } \\
\text { desteklemeli”) }\end{array}$ & 1 & $\begin{array}{l}9 \text { Ekim 2019, } \\
\text { İngilizce }\end{array}$ & $\begin{array}{c}\text { ANADOLU AGENCY (ENG) } \\
\text { @anadoluagency } \\
\text { Cumhurbaşkanlığı Sözcüsü } \\
\text { İbrahim Kalın: } \\
\text { '\#Türkiye'nin \#Syria'nın herhang } \\
\text { bir bölümünü işgal etme niyeti } \\
\text { yok' }\end{array}$ \\
\hline 2 & $\begin{array}{l}10 \text { Ekim } \\
\text { 2019, } \\
\text { Almanca }\end{array}$ & $\begin{array}{c}\text { Türkiye neden } \\
\text { Kuzey Suriye'de } \\
\text { Firat'ın doğusunda } \\
\text { bir askeri } \\
\text { operasyon } \\
\text { yürütüyor? } \\
\text { (Tweet'in altında } \\
\text { operasyonun neden } \\
\text { yapıldığına dair } \\
\text { yazılı bir açıklama } \\
\text { yer almaktadır.) }\end{array}$ & 2 & $\begin{array}{l}9 \text { Ekim 2019, } \\
\text { İngilizce }\end{array}$ & $\begin{array}{c}\text { Ibrahim Kalin } \\
\text { @ikalin1 } \\
\text { Aljazeera ile güvenli bölgedeki } \\
\text { röportajım, mültecilerin geri } \\
\text { dönüşleri ve terörle mücadele. }\end{array}$ \\
\hline 3 & $\begin{array}{l}10 \text { Ekim } \\
\text { 2019, } \\
\text { Almanca }\end{array}$ & $\begin{array}{l}\text { Barış Pınarı } \\
\text { Harekâtı nı } 10 \\
\text { adımda keşfet. }\end{array}$ & 3 & $\begin{array}{l}9 \text { Ekim 2019, } \\
\text { İngilizce }\end{array}$ & $\begin{array}{c}\text { Ibrahim Kalin } \\
@ \text { @ikalin1 } \\
@ \text { BeckyCNN ile röportajım }\end{array}$ \\
\hline
\end{tabular}

\footnotetext{
* Bulgular, Türkiye Berlin Büyükelçiliği resmi Twitter hesabı (https://twitter.com/TC_BerlinBE) üzerinden, 09 Ekim 2019 tarihi ve 14 Kasım 2019 tarihi arasında yapılan harekat ile ilgili paylaşımlardan elde edilmiştir.
} 
Kamu Diplomasisinde Dijital Dönüşüm: Büyükelçilerin Twitter Üzerinden Gerçekleştirdikleri Dijital Diplomasi Faaliyetlerinin İncelenmesi Mesut İris, Tansu Akdemir

\begin{tabular}{|c|c|c|c|c|c|}
\hline & & $\begin{array}{c}\text { (altında yazı ve } \\
\text { resimle } \\
\text { desteklenmiş görsel } \\
\text { yer almaktadır.) }\end{array}$ & & & $\begin{array}{c}\text { Güvenli bölge üzerinde mülteciler } \\
\text { ve Türkiye'nin PKK ve DAEŞ’le } \\
\text { mücadelesi }\end{array}$ \\
\hline 4 & $\begin{array}{c}10 \text { Ekim } \\
\text { 2019, } \\
\text { Almanca } \\
\text { (22 ileti } \\
\text { dizesinden } \\
\text { oluşan } \\
\text { açılama) }\end{array}$ & $\begin{array}{c}\text { Barış Pınarı } \\
\text { Harekâtı na İlişkin } \\
\text { Gerçekler. } \\
\text { Suriye'den } \\
\text { kaynaklanan ve } \\
\text { Türkiye sınırlarına } \\
\text { yönelik terör } \\
\text { tehdidi DAESCH } \\
\text { ile sınırlı değildir. }\end{array}$ & 4 & $\begin{array}{c}9 \text { Ekim 2019, } \\
\text { İngilizce }\end{array}$ & $\begin{array}{c}\text { Mevlüt Çavuşoğlu } \\
\text { @MevlutCavusoglu } \\
\text { (T.C. Diş İşleri Bakanı) } \\
\text { Bu operasyon, uluslararası } \\
\text { hukuka, BM Şartı'nın } 51 . \\
\text { maddesine ve BM Güvenlik } \\
\text { Konseyi'nin terörle mücadeleye } \\
\text { ilişkin kararlarına uygun olarak } \\
\text { yürütülmektedir. }\end{array}$ \\
\hline 5 & $\begin{array}{c}10 \text { Ekim } \\
\text { 2019, } \\
\text { Almanca } \\
\\
\text { (22 ileti } \\
\text { dizesinden } \\
\text { oluşan } \\
\text { açılama) }\end{array}$ & $\begin{array}{c}\text { Son iki yılda, } \\
\text { özellikle Doğu } \\
\text { Fırat'tan, PKK'nın } \\
\text { AB ve NATO'nun } \\
\text { terör örgütü olarak } \\
\text { sınıflandırdığı } \\
\text { Suriye' deki PYD / } \\
\text { YPG'nin yüzlerce } \\
\text { saldırı veya } \\
\text { düşmanca eylemine } \\
\text { maruz kaldık. }\end{array}$ & 5 & $\begin{array}{c}9 \text { Ekim 2019, } \\
\text { İngilizce }\end{array}$ & $\begin{array}{c}\text { Mevlüt Çavuşoğlu } \\
\text { @MevlutCavusoglu } \\
\text { (T.C. Dış İşleri Bakanı) } \\
\text { - Bölge teröristlerden } \\
\text { temizlenecek, } \\
\text { - Suriye'nin sınır güvenliği ve } \\
\text { toprak bütünlüğü güvence altına } \\
\text { alınacak, } \\
\text { - Yerinden olmuş kişiler, evlerine } \\
\text { güvenle geri dönebilecekler, } \\
\text { - Bölgede barış ve güvenlik } \\
\text { hüküm sürecek. }\end{array}$ \\
\hline 6 & $\begin{array}{c}10 \text { Ekim } \\
\text { 2019, } \\
\text { Almanca } \\
\text { (22 ileti } \\
\text { dizesinden } \\
\text { oluşan } \\
\text { açılama) }\end{array}$ & $\begin{array}{l}\text { PYD / YPG ayrıca } \\
\text { Suriye'de ve } \\
\text { Suriyelilere yönelik } \\
\text { terör saldırıları } \\
\text { düzenledi. 200'den } \\
\text { fazla saldırı oldu ve } \\
\text { çok sayıda sivil } \\
\text { öldü ya da } \\
\text { yaralandı. }\end{array}$ & 6 & $\begin{array}{c}9 \text { Ekim 2019, } \\
\text { Türkçe }\end{array}$ & $\begin{array}{c}\text { Recep Tayyip Erdoğan } \\
\text { @RTErdogan } \\
\text { (Türkiye Cumhurbaşkanı ve AK } \\
\text { Parti Genel Başkanı) } \\
\text { Barış Pınarı Harekâtı ile, } \\
\text { Ülkemize yönelik terör tehdidini } \\
\text { bertaraf edeceğiz. } \\
\text { Oluşturacağımız GÜVENLİ } \\
\text { BÖLGE sayesinde Suriyeli } \\
\text { sığınmacıların ülkelerine } \\
\text { dönmelerini sağlayacağı. } \\
\text { Suriye'nin toprak bütünlüğünü } \\
\text { koruyacak, tüm bölge halkını } \\
\text { terörün pençesinden kurtaracağı. }\end{array}$ \\
\hline 7 & $\begin{array}{c}10 \text { Ekim } \\
\text { 2019, } \\
\text { Almanca } \\
\text { (22 ileti } \\
\text { dizesinden } \\
\text { oluşan } \\
\text { açılama) }\end{array}$ & $\begin{array}{l}\text { PYD / YPG ile ilgili } \\
\text { unsurlar, tereddüt } \\
\text { etmeksizin, bunun } \\
\text { sorumluluğunu } \\
\text { üstlendi. }\end{array}$ & 7 & $\begin{array}{c}9 \text { Ekim 2019, } \\
\text { İngilizce }\end{array}$ & $\begin{array}{c}\text { Recep Tayyip Erdoğan } \\
\text { @RTErdogan } \\
\text { (Türkiye Cumhurbaşkanı ve AK } \\
\text { Parti Genel Başkanı) } \\
\text { \#OperationPeaceSpring, } \\
\text { Türkiye'ye yönelik terör } \\
\text { tehditlerini etkisiz hale getirecek } \\
\text { ve Suriyeli mültecilerin evlerine } \\
\text { geri dönmelerini kolaylaştıracak }\end{array}$ \\
\hline
\end{tabular}




\begin{tabular}{|c|c|c|c|c|c|}
\hline & & & & & $\begin{array}{l}\text { güvenli bir bölgenin kurulmasına } \\
\text { yol açacaktır. } \\
\text { Suriye'nin toprak bütünlüğünü } \\
\text { koruyacağız ve yerel toplulukları } \\
\text { teröristlerden kurtaracağız. }\end{array}$ \\
\hline 8 & $\begin{array}{l}10 \text { Ekim } \\
\text { 2019, } \\
\text { Almanca } \\
\text { (22 ileti } \\
\text { dizesinden } \\
\text { oluşan } \\
\text { açıklama) }\end{array}$ & $\begin{array}{c}\text { Türkiye, Kuzeybatı } \\
\text { Suriye'de iki büyük } \\
\text { terörle mücadele } \\
\text { operasyonu (Fırat } \\
\text { Kalkanı / } 2017 \text { ve } \\
\text { Zeytin Dalı / 2018) } \\
\text { gerçekleştirmiştir. }\end{array}$ & 8 & $\begin{array}{l}9 \text { Ekim 2019, } \\
\text { İngilizce }\end{array}$ & $\begin{array}{c}\text { Recep Tayyip Erdoğan } \\
\text { @RTErdogan } \\
\text { (Türkiye Cumhurbaşkanı ve AK } \\
\text { Parti Genel Başkanı) } \\
\text { Türk Silahlı Kuvvetleri, Suriye } \\
\text { Ulusal Ordusu ile birlikte, } \\
\text { Suriye'nin kuzeyindeki PKK / } \\
\text { YPG ve DAEŞ teröristlerine karşı } \\
\text { \#OperationPeaceSpring'i başlattı. } \\
\text { Misyonumuz, güney sinırımız } \\
\text { boyunca terör koridoru } \\
\text { yaratılmasını önlemek ve bölgeye } \\
\text { barış getirmektir. }\end{array}$ \\
\hline 9 & $\begin{array}{l}10 \text { Ekim } \\
2019, \\
\text { Almanca } \\
\text { (22 ileti } \\
\text { dizesinden } \\
\text { oluşan } \\
\text { açıklama) }\end{array}$ & $\begin{array}{l}\text { Türkiye, DAESCH'e } \\
\text { karşı Uluslararası } \\
\text { Koalisyonun kararlı } \\
\text { bir üyesidir. } \\
\text { Türkiye, DAESCH'e } \\
\text { karşı kara } \\
\text { kuvvetleriyle } \\
\text { savaşan tek ülkedir. } \\
\text { Yalnızca 4.000'den } \\
\text { fazla DAESCH } \\
\text { teröristini devre } \\
\text { dışı bıraktık. }\end{array}$ & 9 & $\begin{array}{c}10 \text { Ekim } \\
2019, \\
\text { İngilizce }\end{array}$ & $\begin{array}{c}\text { Jack Posobiec us } \\
@ \text { JackPosobiec } \\
\text { (One America News Network) } \\
3 \text { yıl once } \\
@ \text { LindseyGrahamSC } \\
\text { Suriye'deki PKK ile ilgili gerçeği } \\
\text { anlattı } \\
\text { (video paylaşımı) }\end{array}$ \\
\hline 10 & $\begin{array}{l}10 \text { Ekim } \\
\text { 2019, } \\
\text { Almanca } \\
\text { (22 ileti } \\
\text { dizesinden } \\
\text { oluşan } \\
\text { açıklama) }\end{array}$ & $\begin{array}{l}\text { Artık teröristlerin } \\
\text { sınırlarımızdaki } \\
\text { varlığına tahammül } \\
\text { edemeyiz. } \\
\text { Kaderimizi kendi } \\
\text { ellerimizle almak } \\
\text { zorunda kaldık. }\end{array}$ & 10 & $\begin{array}{c}10 \text { Ekim } \\
2019, \\
\text { İngilizce }\end{array}$ & $\begin{array}{c}\text { DAILY SABAH } \\
\text { @DailySabah } \\
\text { Türkiye'nin Suriye'deki } \\
\text { operasyonu hakkında FM } \\
\text { Çavuşoğlu: } \\
\text { - Türkiye, DAEŞ teröristlerinin } \\
\text { sorumlu tutulmasını sağlamak } \\
\text { için } \\
\text { - PKK / YPG ABD'de "sofistike ve } \\
\text { ağır" silahlara sahip } \\
\text { - Mültecilerin planlanan güvenli } \\
\text { bölgeye geri dönüşleri gönüllü } \\
\text { olarak yapılacaktır. }\end{array}$ \\
\hline
\end{tabular}


Kamu Diplomasisinde Dijital Dönüşüm: Büyükelçilerin Twitter Üzerinden Gerçekleştirdikleri Dijital Diplomasi Faaliyetlerinin İncelenmesi Mesut İris, Tansu Akdemir

\begin{tabular}{|c|c|c|c|c|c|}
\hline 11 & $\begin{array}{l}\text { 10 Ekim } \\
2019, \\
\text { Almanca } \\
\\
\text { (22 ileti } \\
\text { dizesinden } \\
\text { oluşan } \\
\text { açıklama) }\end{array}$ & $\begin{array}{c}\text { Bu yüzden Barış } \\
\text { Pınarı } \\
\text { Operasyonuna } \\
\text { başladık. }\end{array}$ & 11 & $\begin{array}{c}11 \text { Ekim } \\
\text { 2019, } \\
\text { İngilizce }\end{array}$ & $\begin{array}{c}\text { Mevlüt Çavuşoğlu } \\
\text { @MevlutCavusoglu } \\
\text { (T.C. Dış İşleri Bakanı) } \\
\text { Bugünkü röportajım } \\
\text { @NYTimes } \\
\text { OperasyonPeaceSpring: Neden } \\
\text { Türkiye Suriye İle Mücadeleye } \\
\text { Katıldı? }\end{array}$ \\
\hline 12 & $\begin{array}{l}10 \text { Ekim } \\
\text { 2019, } \\
\text { Almanca } \\
\\
\text { (22 ileti } \\
\text { dizesinden } \\
\text { oluşan } \\
\text { açıklama) }\end{array}$ & $\begin{array}{l}\text { Bu operasyonun } \\
\text { temel amacı } \\
\text { Türkiye'nin sınır } \\
\text { güvenliğini } \\
\text { sağlamak, } \\
\text { bölgedeki } \\
\text { teröristleri etkisiz } \\
\text { hale getirmek ve } \\
\text { Suriyelileri bu } \\
\text { teröristlerin baskı } \\
\text { ve zulmünden } \\
\text { korumak. }\end{array}$ & 12 & $\begin{array}{c}11 \text { Ekim } \\
\text { 2019, } \\
\text { İngilizce }\end{array}$ & $\begin{array}{c}\text { Yavuz Selim KIRAN } \\
\text { @yavuzselimkiran } \\
\text { (T.C. Dışişleri Bakan Yardımcısı) } \\
5 \text { soruda Türkiye'nin } \\
\text { \#OperationPeaceSpring'i. } \\
\text { - Barış Pınarı Operasyonu Nedir? } \\
\text { - Bölgede Terörist Gruplar Aktif } \\
\text { mi? } \\
\text { • Amacı Nedir? } \\
\text { • Bu neye bağlıdır? } \\
\text { • Emsaller? } \\
\text { (video paylaşımı) }\end{array}$ \\
\hline 13 & $\begin{array}{l}10 \text { Ekim } \\
\text { 2019, } \\
\text { Almanca } \\
\\
\text { (22 ileti } \\
\text { dizesinden } \\
\text { oluşan } \\
\text { açıklama) }\end{array}$ & $\begin{array}{c}\text { Firat Kalkanı ve } \\
\text { Zeytin Dalı } \\
\text { operasyonlarında } \\
\text { olduğu gibi } \\
\text { operasyonun } \\
\text { planlama ve } \\
\text { uygulama } \\
\text { aşamasında ise } \\
\text { sadece terörist } \\
\text { unsurlar ve onların } \\
\text { saklanma yerleri, } \\
\text { barınaklar, } \\
\text { pozisyonlar, } \\
\text { silahlar, araçlar ve } \\
\text { teçhizatlar } \\
\text { hedeflenmektedir. }\end{array}$ & 13 & $\begin{array}{c}12 \text { Ekim } \\
\text { 2019, } \\
\text { İngilizce }\end{array}$ & $\begin{array}{c}\text { Fahrettin Altun } \\
\text { @fahrettinaltun } \\
\text { (İletişim Başkanı, Türkiye } \\
\text { Cumhuriyeti) } \\
\text { PKK-YPG ilişkisi, siz de dahil } \\
\text { olmak üzere ABD yetkilileri } \\
\text { tarafından iyi bilinmektedir. } \\
\text { @LindseyGrahamSC } \\
\text { Sonunda, Başkan Trump, Obama } \\
\text { yönetimini bu konuda eleştirdi. } \\
\text { Senatör, “Türkiye Suriye } \\
\text { Kürtlerine saldırıyor” demek } \\
\text { ikiyüzlülük değil mi? } \\
\text { (video paylaşımı) }\end{array}$ \\
\hline 14 & $\begin{array}{l}10 \text { Ekim } \\
2019, \\
\text { Almanca } \\
\text { (22 ileti } \\
\text { dizesinden } \\
\text { oluşan } \\
\text { açıklama) }\end{array}$ & $\begin{array}{l}\text { Operasyon } \\
\text { uluslararası hukuk } \\
\text { temelinde ve } \\
\text { Birleşmiş Milletler } \\
\text { Tüzüğ̈̈'nün } 51 \text { inci } \\
\text { Maddesinde yer } \\
\text { alan öz savunma } \\
\text { hakkına ve ilgili } \\
\text { Güvenlik Konseyi } \\
\text { kararlarına uygun } \\
\text { olarak } \\
\text { gerçekleştirilecektir. }\end{array}$ & 14 & $\begin{array}{c}13 \text { Ekim } \\
2019, \\
\text { İngilizce }\end{array}$ & $\begin{array}{c}\text { Fahrettin Altun } \\
\text { @fahrettinaltun } \\
\text { (İletişim Başkanı, Türkiye } \\
\text { Cumhuriyeti) } \\
\text { Türkiye, DEASH'la mücadeleyi } \\
\text { sürdürmeye odaklanmış ve } \\
\text { kararlı ve aynı zamanda bu } \\
\text { korkak teröristlerle savaşmaya } \\
\text { tamamen adanmış bir ülke. } \\
\text { DEASH, Türkiye'nin bir } \\
\text { düşmanıdır ve biz tamamen yok } \\
\text { edene kadar onlarla savaşmayı } \\
\text { bırakmayacağı. }\end{array}$ \\
\hline
\end{tabular}




\begin{tabular}{|c|c|c|c|c|c|}
\hline & & & & & (video paylaşımı) \\
\hline 15 & $\begin{array}{l}10 \text { Ekim } \\
\text { 2019, } \\
\text { Almanca } \\
\\
\text { (22 ileti } \\
\text { dizesinden } \\
\text { oluşan } \\
\text { açıklama) }\end{array}$ & $\begin{array}{l}\text { Bölgede daha fazla } \\
\text { terörist olmayana, } \\
\text { sınır güvenliğimiz } \\
\text { sağlanana ve yerel } \\
\text { Suriye nüfusu PYD } \\
\text { / YPG ve DAESCH } \\
\text { tehditlerinin } \\
\text { zorbalığından } \\
\text { kurtulana kadar } \\
\text { operasyonu } \\
\text { sürdürmeyi } \\
\text { planlıyoruz. }\end{array}$ & 15 & $\begin{array}{c}14 \text { Ekim } \\
\text { 2019, } \\
\text { İngilizce }\end{array}$ & $\begin{array}{c}\text { Ibrahim Kalin } \\
\text { @ikalin1 } \\
\text { Türkiye, Kürtlere değil PKK'ya ve } \\
\text { DAEŞ teröristlerine karşı } \\
\text { savaşıor. } \\
\text { Amaç sınırımızı temizleyip } \\
\text { mültecilerin güvenli bir şekilde } \\
\text { evlerine dönmelerini sağlamak. } \\
\text { Dünya PKK / YPG } \\
\text { propagandasına katılmak yerine } \\
\text { Türkiye'yi desteklemeli. }\end{array}$ \\
\hline 16 & $\begin{array}{l}10 \text { Ekim } \\
\text { 2019, } \\
\text { Almanca } \\
\\
\text { (22 ileti } \\
\text { dizesinden } \\
\text { oluşan } \\
\text { açıklama) }\end{array}$ & $\begin{array}{c}\text { Amacımız, } \\
\text { yerinden edilmiş } \\
\text { Suriyelilerin } \\
\text { güvenli ve gönüllü } \\
\text { geri dönüşünü } \\
\text { kolaylaştırmaktır. } \\
\text { Bir güvenlik } \\
\text { bölgesi, Türkiye'ye } \\
\text { sı̆̆ınan 300.000'den } \\
\text { fazla Suriyeli Kürt } \\
\text { dahil olmak üzere } \\
\text { bu Suriyelileri } \\
\text { gönüllü olarak } \\
\text { vatanlarına geri } \\
\text { dönmeye teşvik } \\
\text { edecektir. }\end{array}$ & 16 & $\begin{array}{c}14 \text { Ekim } \\
\text { 2019, } \\
\text { İngilizce }\end{array}$ & $\begin{array}{c}\text { Ibrahim Kalin } \\
\text { @ikalin1 } \\
\text { Binlerce sivil öldürüldüğünde } \\
\text { Musul, Rakka ve Dayrzor'da } \\
\text { şehirler yerleştiğinde, teröristler } \\
\text { silahlandığında sessiz kaldılar. } \\
\text { Şimdi Türkiye'yi teröristlerle } \\
\text { mücadelesini durdurması için } \\
\text { baskı altına almaya çalışıyorlar. } \\
\text { Türkiye'nin sipariş günleri sona } \\
\text { erdi. }\end{array}$ \\
\hline 17 & $\begin{array}{l}10 \text { Ekim } \\
\text { 2019, } \\
\text { Almanca } \\
\\
\text { (22 ileti } \\
\text { dizesinden } \\
\text { oluşan } \\
\text { açıklama) }\end{array}$ & $\begin{array}{c}\text { Aslında, } \\
\text { Türkiye'nin } \\
\text { toprakları } \\
\text { terörizmden } \\
\text { kurtarmak ve } \\
\text { Suriyelilerin } \\
\text { güvenli ve gönüllü } \\
\text { geri dönüşlerini } \\
\text { kolaylaştırmak için } \\
\text { köklü bir politikası } \\
\text { vardır. }\end{array}$ & 17 & $\begin{array}{c}14 \text { Ekim } \\
\text { 2019, } \\
\text { İngilizce }\end{array}$ & $\begin{array}{c}\text { Fahrettin Altun } \\
\text { @fahrettinaltun } \\
\text { (İletişim Başkanı, Türkiye } \\
\text { Cumhuriyeti) } \\
\text { Batılı hükümetler vatandaşlarına } \\
\text { Suriye konusunda yalan } \\
\text { söylüyorlar. } \\
\text { PKK'nın geri dönmeleri } \\
\text { durumunda onları } \\
\text { öldüreceğinden korkan yüz } \\
\text { binlerce Suriyeli Kürt Türkiye'de } \\
\text { hala yaşıor. }\end{array}$ \\
\hline
\end{tabular}


Kamu Diplomasisinde Dijital Dönüşüm: Büyükelçilerin Twitter Üzerinden Gerçekleştirdikleri Dijital Diplomasi Faaliyetlerinin İncelenmesi Mesut İris, Tansu Akdemir

\begin{tabular}{|c|c|c|c|c|c|}
\hline 18 & $\begin{array}{l}10 \text { Ekim } \\
\text { 2019, } \\
\text { Almanca } \\
\text { (22 ileti } \\
\text { dizesinden } \\
\text { oluşan } \\
\text { açıklama) }\end{array}$ & $\begin{array}{c}\text { Kuzeybatı } \\
\text { Suriye'de, } \\
\text { 360.000'den fazla } \\
\text { Suriyeli, Fırat ve } \\
\text { Zeytin Dalı } \\
\text { operasyonları } \\
\text { sirasında } \\
\text { teröristlerden } \\
\text { kurtulan } \\
\text { bölgelerden } \\
\text { memleketlerine } \\
\text { döndüler. }\end{array}$ & 18 & $\begin{array}{l}15 \text { Ekim } \\
2019, \\
\text { İngilizce }\end{array}$ & $\begin{array}{c}\text { Fahrettin Altun } \\
\text { @fahrettinaltun } \\
\text { (İletişim Başkanı, Türkiye } \\
\text { Cumhuriyeti) } \\
\text { Devlet Başkanı } \\
\text { @RTErdogan } \\
\text { bugün bir açıklama yayınladı } \\
\text { @WSJ } \\
\text { “Uluslararası toplum Suriye } \\
\text { krizini önleme fırsatını kaçırdı \# } \\
\text { OperationPeaceSpring bölgeye } \\
\text { barışı ve istikrarı sağlamak için } \\
\text { ikinci bir şansı temsil ediyor.” }\end{array}$ \\
\hline 19 & $\begin{array}{l}10 \text { Ekim } \\
\text { 2019, } \\
\text { Almanca } \\
\text { (22 ileti } \\
\text { dizesinden } \\
\text { oluşan } \\
\text { açılama) }\end{array}$ & $\begin{array}{c}\text { Türkiye, operasyon } \\
\text { alanındaki } \\
\text { demografik yapıyı } \\
\text { değiştirmeyi } \\
\text { planlamamaktadır. }\end{array}$ & 19 & $\begin{array}{c}16 \text { Ekim } \\
\text { 2019, Türkçe }\end{array}$ & $\begin{array}{c}\text { Mevlüt Çavuşoğlu } \\
\text { @MevlutCavusoglu } \\
\text { (T.C. Dış İşleri Bakanı) } \\
\text { Ülkemizin güvenliği ve } \\
\text { bölgemizde barış\&istikrarın tesisi } \\
\text { için başlatılan } \\
\text { \#BarışPınarıHarekâtı hakkında } \\
\text { Gazi Meclisimizde } \\
\text { milletvekillerimizi bilgilendirdik. } \\
\text { Terör örgütlerine karşı } \\
\text { mücadelemizi kararlılıkla } \\
\text { sürdürecek, sınırlarımızı } \\
\text { teröristlerden temizleyeceğiz. } \\
\text { \#BizTürkiyeyiz } \\
\end{array}$ \\
\hline 20 & $\begin{array}{l}10 \text { Ekim } \\
\text { 2019, } \\
\text { Almanca } \\
\text { (22 ileti } \\
\text { dizesinden } \\
\text { oluşan } \\
\text { açıklama) }\end{array}$ & $\begin{array}{l}\text { Operasyon, Kürtler, } \\
\text { Araplar ve } \\
\text { Hristiyanlar dahil } \\
\text { olmak üzere en az } \\
\text { bir milyon yerinden } \\
\text { edilmiş Suriyeli'nin } \\
\text { PYD / YPG'nin } \\
\text { etnik temizliğinin } \\
\text { kurbanı olduktan } \\
\text { sonra atalarının } \\
\text { topraklarına } \\
\text { dönmelerini } \\
\text { sağlayacak. } \\
\end{array}$ & 20 & $\begin{array}{l}17 \text { Ekim } \\
\text { 2019, } \\
\text { Almanca }\end{array}$ & $\begin{array}{c}\text { T.C. Essen BK } \\
\text { @TC_Essen } \\
\text { T.C. Essen Başkonsolosluğu } \\
\text { Resmi Twitter Hesabı } \\
\text { Terör örgütü PKK / YPG-PYD'nin } \\
\text { destekçileri dün gece } \\
\text { Lüdenscheid'de vatandaşlarımıza } \\
\text { saldırdı. }\end{array}$ \\
\hline 21 & $\begin{array}{l}\text { 10 Ekim } \\
\text { 2019, } \\
\text { Almanca } \\
\text { (22 ileti } \\
\text { dizesinden } \\
\text { oluşan } \\
\text { açıklama) }\end{array}$ & $\begin{array}{l}\text { Türkiye'nin } \\
\text { Suriye'deki terörle } \\
\text { mücadele çabaları, } \\
\text { ayrılıkçı } \\
\text { gündemleri } \\
\text { durdurarak } \\
\text { Suriye'nin toprak } \\
\text { bütünlüğüne ve }\end{array}$ & 21 & $\begin{array}{l}19 \text { Ekim } \\
\text { 2019, Türkçe }\end{array}$ & $\begin{array}{c}\text { Mevlüt Çavuşoğlu } \\
\text { @MevlutCavusoglu } \\
\text { (T.C. Diş İşleri Bakanı) } \\
\text { Gerçekleri; çekinmeden, cesurca } \\
\text { söyleyenler de var! } \\
\text { @sigmargabriel } \\
\text { (video paylaşımı) }\end{array}$ \\
\hline
\end{tabular}




\begin{tabular}{|c|c|c|c|c|c|}
\hline & & $\begin{array}{c}\text { birliğine katkıda } \\
\text { bulunacaktır. }\end{array}$ & & & \\
\hline 22 & $\begin{array}{l}10 \text { Ekim } \\
\text { 2019, } \\
\text { Almanca } \\
\text { (22 ileti } \\
\text { dizesinden } \\
\text { oluşan } \\
\text { açılama) }\end{array}$ & $\begin{array}{c}\text { Tutuklanan } \\
\text { DAESCH } \\
\text { teröristlerinin } \\
\text { geleceği Türkiye } \\
\text { için büyük önem } \\
\text { taşıyor. } \\
\text { Sürdürülebilir tek } \\
\text { çözüm, tüm } \\
\text { yabancı teröristlerin } \\
\text { menşe ülkeleri } \\
\text { tarafından geri } \\
\text { gönderilmesi. } \\
\end{array}$ & 22 & $\begin{array}{c}19 \text { Ekim } \\
\text { 2019, Türkçe }\end{array}$ & $\begin{array}{l}\text { T.C. Cumhurbaşkanlığı } \\
\text { @tcbestepe } \\
\text { “Ülkemize verilen sözler } \\
\text { tutulmazsa verdiğimiz süre bittiği } \\
\text { an harekâta devam edeceğiz” }\end{array}$ \\
\hline 23 & $\begin{array}{l}\text { 10 Ekim } \\
2019, \\
\text { Almanca } \\
\text { (22 ileti } \\
\text { dizesinden } \\
\text { oluşan } \\
\text { açiklama) }\end{array}$ & $\begin{array}{l}\text { Yabancı } \\
\text { teröristlerin sorunu } \\
\text { ancak uluslararası } \\
\text { toplumun ortak } \\
\text { hareketi ile etkili bir } \\
\text { şekilde çözülebilir. }\end{array}$ & 23 & $\begin{array}{l}19 \text { Ekim } \\
\text { 2019, } \\
\text { İngilizce ve } \\
\text { Türkçe }\end{array}$ & $\begin{array}{l}\text { Mevlüt Çavuşoğlu } \\
\text { @MevlutCavusoglu } \\
\text { (T.C. Dış İşleri Bakanı) } \\
\text { Yerinde tespit! } \\
\text { Well said! } \\
\text { (video paylaşımı) }\end{array}$ \\
\hline 24 & $\begin{array}{l}10 \text { Ekim } \\
\text { 2019, } \\
\text { Almanca } \\
\text { (22 ileti } \\
\text { dizesinden } \\
\text { oluşan } \\
\text { açılama) }\end{array}$ & $\begin{array}{c}\text { Sivil nüfusu ve sivil } \\
\text { altyapıyı korumak } \\
\text { bizim } \\
\text { önceliğimizdir. }\end{array}$ & 24 & $\begin{array}{l}20 \text { Ekim } \\
2019, \\
\text { İngilizce }\end{array}$ & $\begin{array}{c}\text { Fahrettin Altun } \\
\text { @fahrettinaltun } \\
\text { (Illetişim Başkanı, Türkiye } \\
\text { Cumhuriyeti) } \\
\text { DEASH ile mücadeleyi } \\
\text { baltaladığımız tüm yorumlar kötü } \\
\text { niyetli ve temelsizdir. } \\
\text { Türkiye bu örgütle el ele } \\
\text { mücadele eden tek devlettir. } \\
\text { Bütün dünya Türkiye'nin } \\
\text { mücadelesini unutmuş } \\
\text { görünüyor. } \\
\text { Size hatırlatalım. } \\
\text { \#OperationPeaceSpring } \\
\text { (video paylaşımı) }\end{array}$ \\
\hline 25 & $\begin{array}{l}10 \text { Ekim } \\
2019, \\
\text { Almanca } \\
\text { (22 ileti } \\
\text { dizesinden } \\
\text { oluşan } \\
\text { açlklama) }\end{array}$ & $\begin{array}{l}\text { Türkiye, DAESCH } \\
\text { ile mücadele } \\
\text { çabalarında her } \\
\text { zaman ön planda } \\
\text { olmuştur. Bunu } \\
\text { yapmaya devam } \\
\text { edeceğiz. }\end{array}$ & 25 & $\begin{array}{l}22 \text { Ekim } \\
\text { 2019, Türkçe }\end{array}$ & $\begin{array}{c}\text { Mevlüt Çavuş̧oğlu } \\
\text { @MevlutCavusoglu } \\
\text { (T.C. Dış İşleri Bakanı) } \\
\text { Sayın Cumhurbaşkanımız } \\
\text { @RTErdogan'ın liderliğinde; } \\
\text { \#SahadaveMasadaGüçlüTürkiyetR } \\
\text { (Görsel paylaşımı) }\end{array}$ \\
\hline
\end{tabular}


Kamu Diplomasisinde Dijital Dönüşüm:

\begin{tabular}{|c|c|c|c|c|c|}
\hline 26 & $\begin{array}{l}11 \text { Ekim } \\
\text { 2019, } \\
\text { Almanca }\end{array}$ & $\begin{array}{l}\text { Sayın Büyükelçi Ali } \\
\text { Kemal Aydın'ın } \\
\text { Operasyonla İlgili } \\
\text { Yazısı } \\
\text { Barış Pınarı } \\
\text { "11.10.2019" }\end{array}$ & 26 & $\begin{array}{l}22 \text { Ekim } \\
\text { 2019, } \\
\text { İngilizce }\end{array}$ & $\begin{array}{c}\text { Mevlüt Çavuşoğlu } \\
\text { @MevlutCavusoglu } \\
\text { (T.C. Dış İşleri Bakanı) } \\
\text { Sayın Cumhurbaşkanımız } \\
\text { @RTErdogan } \\
\text { 'ın liderliğinde; } \\
\text { \#SahadaveMasadaGüçlüTürkiyetR } \\
\text { (Görsel paylaşımı) }\end{array}$ \\
\hline 27 & $\begin{array}{l}\text { 12 Ekim } \\
\text { 2019, } \\
\text { Almanca }\end{array}$ & $\begin{array}{c}\text { Türkiye } \\
\text { büyükelçisi: } 300.000 \\
\text { Suriyeli Kürt, } \\
\text { Türkiye'ye sığındı. } \\
\\
\text { (haber paylaşımı) }\end{array}$ & 27 & $\begin{array}{l}22 \text { Ekim } \\
\text { 2019, } \\
\text { İngilizce }\end{array}$ & $\begin{array}{c}\text { Faruk Kaymakcı } \\
\text { @frkkymkc } \\
\text { (Türkiye Dışişleri Bakan } \\
\text { Yardımcısı ve Avrupa Birliği } \\
\text { Başkanı, Büyükelçi) } \\
\text { Bu yıllarca Türkiye'nin aradığı ve } \\
\text { aylarca böyle yaptığı şey. } \\
\text { Avrupa'nın geri kalanı DEASH ve } \\
\text { PKK / PYD / YPG'ye karşı } \\
\text { mücadele etmek, kendi ve NATO } \\
\text { ve Avrupa sınırlarını güvence } \\
\text { altına almak, ek göçü önlemek ve } \\
\text { Suriyelilerin güvenli ve gönüllü } \\
\text { geri dönüşünü sağlamak için TR'e } \\
\text { teşekkür etmeli } \\
\text { @dwnews } \\
\text { (video paylaşımı) }\end{array}$ \\
\hline 28 & $\begin{array}{l}\text { 12 Ekim } \\
\text { 2019, } \\
\text { Almanca }\end{array}$ & $\begin{array}{c}11 \text { Ekim 2019, } \\
\text { Uluslararası Barış } \\
\text { Pınarı Operasyonu } \\
\text { Üzerine Bazı } \\
\text { Yorumlara İlişkin } \\
\text { Basın Bülteni }\end{array}$ & 28 & $\begin{array}{c}23 \text { Ekim } \\
2019, \\
\text { İngilizce }\end{array}$ & $\begin{array}{c}\text { Ibrahim Kalin } \\
\text { @ikalin1 } \\
\text { Türkiye: Avrupalılar } \\
\text { 'askerlerimize şükretmeli' } \\
\text {-İdlib'de ve Suriye'nin diğer } \\
\text { bölgelerinde sivilleri korumak ve } \\
\text { mültecilere yardım etmek, } \\
\text { Suriye'nin toprak bütünlüğünü } \\
\text { sağlamak, } \\
\text {-Bölgesel güvenlikte kilit rol } \\
\text { oynamak. }\end{array}$ \\
\hline 29 & $\begin{array}{c}12 \text { Ekim } \\
2019, \\
\text { Almanca }\end{array}$ & $\begin{array}{c}\text { 11 Ekim 2019, } \\
\text { Dışişleri Bakanlığı } \\
\text { sözcüsü, BM } \\
\text { Mülteci Ajansı } \\
\text { Bölge Koordinatörü } \\
\text { tarafından } \\
\text { Kuzeydoğu } \\
\text { Suriye'de kurulan } \\
\text { güvenlik bölgesi } \\
\text { hakkında basında } \\
\text { çıan bir bildiriye } \\
\text { yanıt verdi }\end{array}$ & 29 & $\begin{array}{c}24 \text { Ekim } \\
2019, \\
\text { İngilizce }\end{array}$ & $\begin{array}{c}\text { Verteidigungsministerium } \\
\text { @BMVg_Bundeswehr } \\
\text { (Federal Savunma Bakanlığı, } \\
\text { Basın ve Enformasyon Personeli.) } \\
\text { Uluslararası bir güvenlik bölgesi } \\
\text { ile ilgili tartışmada (@UN-) Kuzey } \\
\text { Suriye'de kontrol için Türkiye ile } \\
\text { konuşmak önemlidir. Bu yüzden } \\
\text { Savunma Bakanı Kramp- } \\
\text { Karrenbauer } \\
\text { Brüksel'de meslektaşı Hulusi } \\
\text { Akar ile biraraya geldi. }\end{array}$ \\
\hline
\end{tabular}




\begin{tabular}{|c|c|c|c|c|c|}
\hline 30 & $\begin{array}{l}12 \text { Ekim } \\
\text { 2019, } \\
\text { Almanca }\end{array}$ & $\begin{array}{c}\text { Sayın Mevlüt } \\
\text { Çavuşoğlu'nun } \\
\text { yazısı, } \\
11 \text { Ekim 2019'da } \\
\text { New York Times'ta } \\
\text { yayınlandı } \\
\end{array}$ & 30 & $\begin{array}{c}\text { 26 Ekim } \\
\text { 2019, } \\
\text { İngilizce ve } \\
\text { Türkçe }\end{array}$ & $\begin{array}{c}\text { Mevlüt Çavuşoğlu } \\
\text { @MevlutCavusoglu } \\
\text { (T.C. Dış İşleri Bakanı) } \\
\text { Once a terrorist always a terrorist! } \\
\text { Terörist her zaman teröristtir! }\end{array}$ \\
\hline 31 & $\begin{array}{l}12 \text { Ekim } \\
\text { 2019, } \\
\text { Almanca }\end{array}$ & $\begin{array}{c}12 \text { Ekim 2019, } \\
\text { Dışişleri Bakanlığı } \\
\text { Sözcüsü Hami } \\
\text { Aksoy, Barış Pınarı } \\
\text { Operasyonu } \\
\text { altındaki } \\
\text { tutukluların ve } \\
\text { ailelerinin kaderiyle } \\
\text { ilgili bir soruya } \\
\text { cevap verdi }\end{array}$ & 31 & $\begin{array}{c}26 \text { Ekim } \\
\text { 2019, } \\
\text { İngilizce ve } \\
\text { Türkçe }\end{array}$ & $\begin{array}{c}\text { Mevlüt Çavuşoğlu } \\
\text { @MevlutCavusoglu } \\
\text { (T.C. Dış İşleri Bakanı) } \\
\text { \#Almanya Dışişleri Bakanı Heiko } \\
\text { Maas'la görüşmemizde \#Suriye } \\
\text { başta olmak üzere ikili } \\
\text { ilişkilerimizi ele aldık. } \\
\text { At our meeting w/FM } \\
\text { @HeikoMaas } \\
\text { of \#Germany, discussed \#Syria } \\
\text { and bilateral relations. }\end{array}$ \\
\hline 32 & $\begin{array}{l}13 \text { Ekim } \\
\text { 2019, } \\
\text { Almanca }\end{array}$ & $\begin{array}{l}\text { Uluslararası Af } \\
\text { Örgütü Suriye } \\
\text { Kürtlerini tahliye } \\
\text { etmekle suçladı. } \\
\text { (haber paylaşımı) }\end{array}$ & 32 & $\begin{array}{c}26 \text { Ekim } \\
\text { 2019, Türkçe }\end{array}$ & $\begin{array}{c}\text { Yavuz Selim KIRAN } \\
\text { @yavuzselimkiran } \\
\text { T.C. Dışişleri Bakan Yardımcısı } \\
\text { Bakanımız } \\
\text { @MevlutCavusoglu: } \\
\text { PKK yandaşları Almanya'da } \\
\text { yaşayan vatandaşlarımıza ve Türk } \\
\text { toplumuna yönelik çok sayıda } \\
\text { saldırı düzenledi. } \\
\text { Alman güvenlik makamlarından } \\
\text { bu olaylara mahal vermemesini } \\
\text { Türk toplumunu,çıkarlarını } \\
\text { korunması için gerekli tüm } \\
\text { önlemleri almasını bekliyoruz. }\end{array}$ \\
\hline 33 & $\begin{array}{l}13 \text { Ekim } \\
\text { 2019, } \\
\text { Almanca }\end{array}$ & $\begin{array}{l}\text { Türkiye Büyükelçisi } \\
\text { askeri } \\
\text { operasyonları } \\
\text { savundu } \\
\text { (haber paylaşımı) }\end{array}$ & 33 & $\begin{array}{c}27 \text { Ekim } \\
\text { 2019, Türkçe }\end{array}$ & $\begin{array}{c}\text { T.C. İletişim Başkanlığı } \\
\text { @iletisim } \\
\text { Türkiye Cumhuriyeti İletişim } \\
\text { Başkanlığı Resmi Twitter Hesabı } \\
\text { Cumhurbaşkanımız } \\
\text { @RTErdogan } \\
\text { Almanya Başbakanı Angela } \\
\text { Merkel ile telefonda görüştü. } \\
\text { Görüşmede, Suriye'nin } \\
\text { Kuzeydoğusuna ilişkin } \\
\text { gelişmelerin yanı sıra ikili ve } \\
\text { bölgesel konular ele alındı. }\end{array}$ \\
\hline
\end{tabular}


Kamu Diplomasisinde Dijital Dönüşüm:

\begin{tabular}{|c|c|c|c|c|c|}
\hline 34 & $\begin{array}{l}\text { 14 Ekim } \\
\text { 2019, } \\
\text { Almanca }\end{array}$ & $\begin{array}{l}13 \text { Ekim 2019, } \\
\text { PKK'nın } \\
\text { yurtdısındaki } \\
\text { şiddetli saldırı, } \\
\text { gösteri ve eylem } \\
\text { sayısının artması } \\
\text { üzerine basın } \\
\text { açıklaması }\end{array}$ & 34 & $\begin{array}{l}27 \text { Ekim } \\
\text { 2019, } \\
\text { Ingilizce }\end{array}$ & $\begin{array}{c}\text { Recep Tayyip Erdoğan } \\
\text { @RTErdogan } \\
\text { Türkiye Cumhurbaşkanı ve AK } \\
\text { Parti Genel Başkanı } \\
\text { DAESH'in elebaşının } \\
\text { öldürülmesi, terörizmle ortak } \\
\text { mücadelemizde bir dönüm } \\
\text { noktasıdır. Türkiye, geçmişte } \\
\text { olduğu gibi, terörle mücadele } \\
\text { çabalarını desteklemeye devam } \\
\text { edecek. }\end{array}$ \\
\hline 35 & $\begin{array}{l}14 \text { Ekim } \\
\text { 2019, } \\
\text { Türkçe }\end{array}$ & $\begin{array}{l}\text { Cumhurbaşkanı } \\
\text { Avrupa'yı tehdit } \\
\text { etmedi, uyardı - } \\
\text { Avrupa Haberleri } \\
\text { (haber paylaşımı) }\end{array}$ & 35 & $\begin{array}{l}27 \text { Ekim } \\
\text { 2019, } \\
\text { İngilizce }\end{array}$ & $\begin{array}{c}\text { Recep Tayyip Erdoğan } \\
\text { @RTErdogan } \\
\text { Türkiye Cumhurbaşkanı ve AK } \\
\text { Parti Genel Başkanı } \\
\text { Türkiye, DAEŞ, PKK / YPG ve } \\
\text { diğer terör örgütleriyle } \\
\text { mücadelede en değerli bedeli } \\
\text { ödeyen Türkiye, bu gelişmeyi } \\
\text { memnuniyetle karşılıyor. } \\
\text { İttifak ruhu doğrultusunda } \\
\text { terörizme karşı kararlı bir } \\
\text { mücadelenin tüm insanlığa barış } \\
\text { getireceğine eminim. } \\
\end{array}$ \\
\hline 36 & $\begin{array}{l}15 \text { Ekim } \\
\text { 2019, } \\
\text { Almanca }\end{array}$ & $\begin{array}{l}14 \text { Ekim 2019, AB } \\
\text { Dış İlişkiler } \\
\text { Konseyi tarafından } \\
\text { kabul edilen } \\
\text { sonuçlara ilişkin } \\
\text { basın açılaması }\end{array}$ & 36 & $\begin{array}{l}2 \text { Kasım } \\
\text { 2019, } \\
\text { İngilizce }\end{array}$ & $\begin{array}{c}\text { Ibrahim Kalin } \\
\text { @ikalin1 } \\
\text { YPG teröristleri Tal Abyad'daki } \\
\text { bir pazardaki saldırıda bugün } 13 \\
\text { kişiyi öldürdü ve } 20 \text { kişiyi } \\
\text { yaraladı. } \\
\text { Bu bir kez daha bu terör } \\
\text { örgütünün gerçek yüzünü } \\
\text { gösteriyor. } \\
\text { Türkiye terörle mücadeleye her } \\
\text { türlü şekli ve biçimde devam } \\
\text { edecektir. }\end{array}$ \\
\hline 37 & $\begin{array}{l}15 \text { Ekim } \\
\text { 2019, } \\
\text { Almanca }\end{array}$ & $\begin{array}{l}\text { Ali Kemal Aydın: } \\
\text { "Müttefikler } \\
\text { arasında yaptırım } \\
\text { olmamalı" }\end{array}$ & 37 & $\begin{array}{l}2 \text { Kasım } \\
2019, \\
\text { İngilizce }\end{array}$ & $\begin{array}{c}\text { Mevlüt Çavuşoğlu } \\
\text { @MevlutCavusoglu } \\
\text { (T.C. Dış İşleri Bakanı) } \\
\text { Tal Abyad'daki masum sivilleri } \\
\text { hedef alan saldırı, YPG terör } \\
\text { örgütüne barınma sağlayan ve } \\
\text { eylemlerini haklı kılanlara bir } \\
\text { ders olmalı. Bu korkunç saldırı bir } \\
\text { kez daha ne kadar doğru ve } \\
\text { zamanında olduğunu kanıtlıyor }\end{array}$ \\
\hline
\end{tabular}




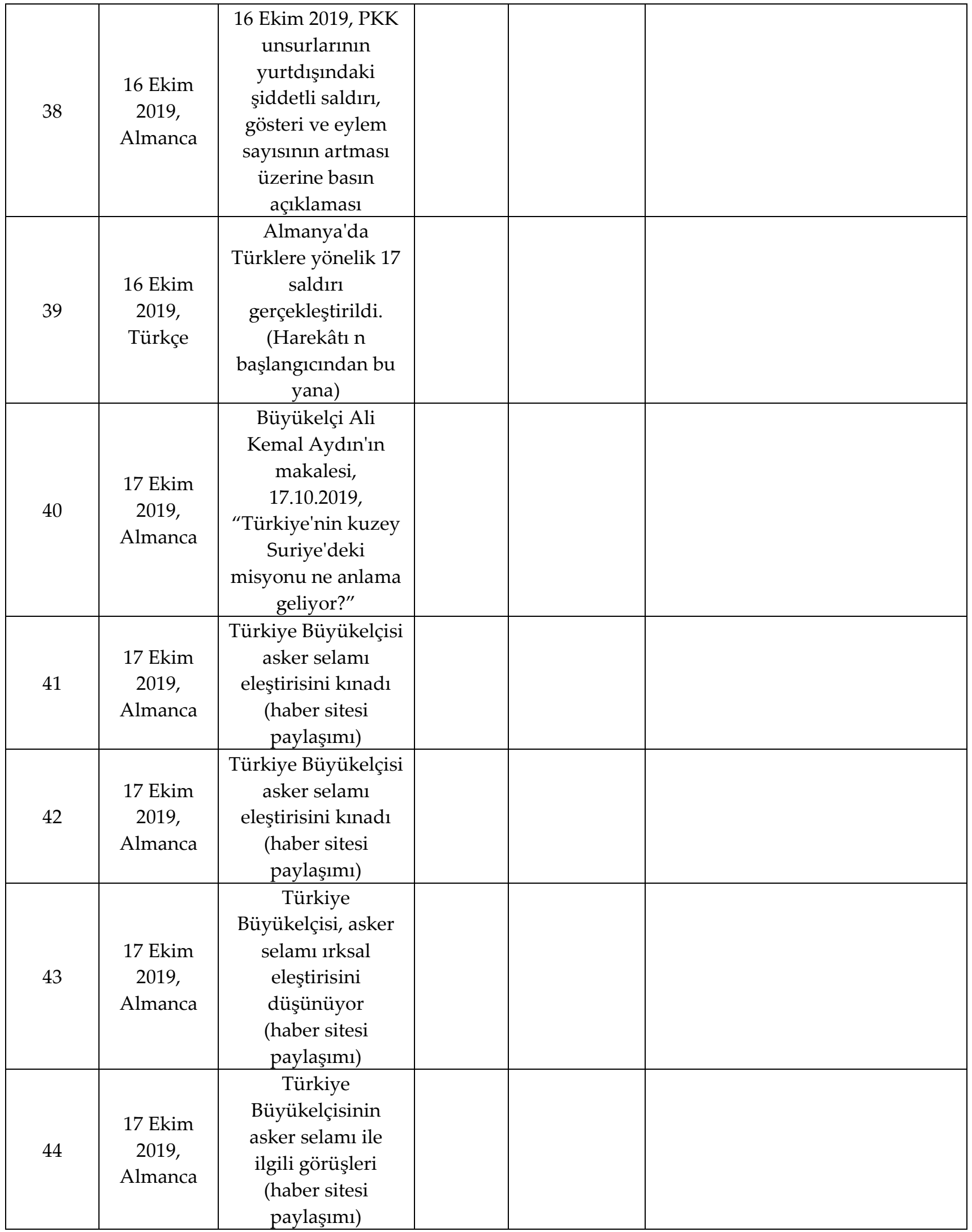


Kamu Diplomasisinde Dijital Dönüşüm: Büyükelçilerin Twitter Üzerinden Gerçekleştirdikleri Dijital Diplomasi Faaliyetlerinin İncelenmesi Mesut İris, Tansu Akdemir

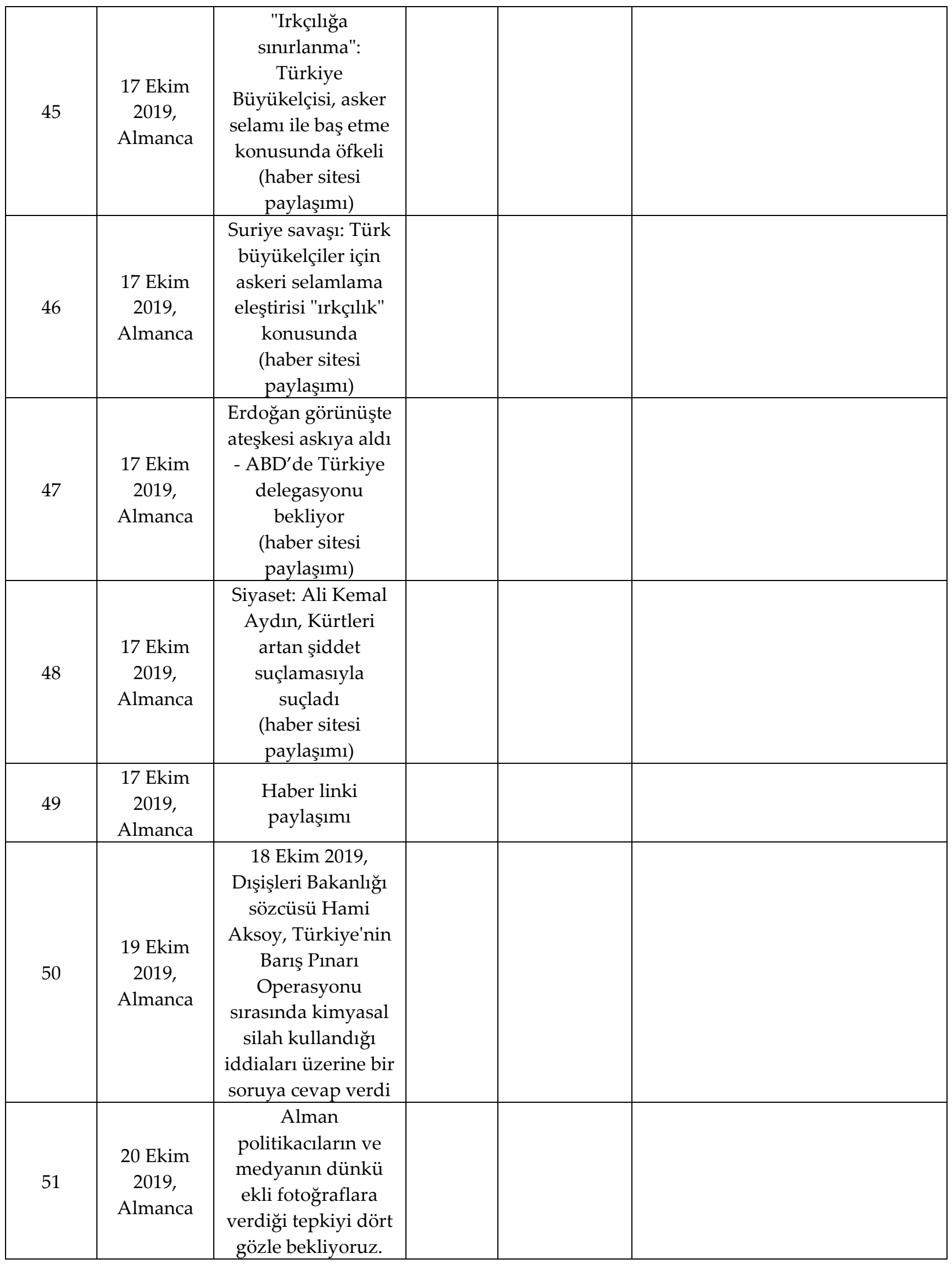




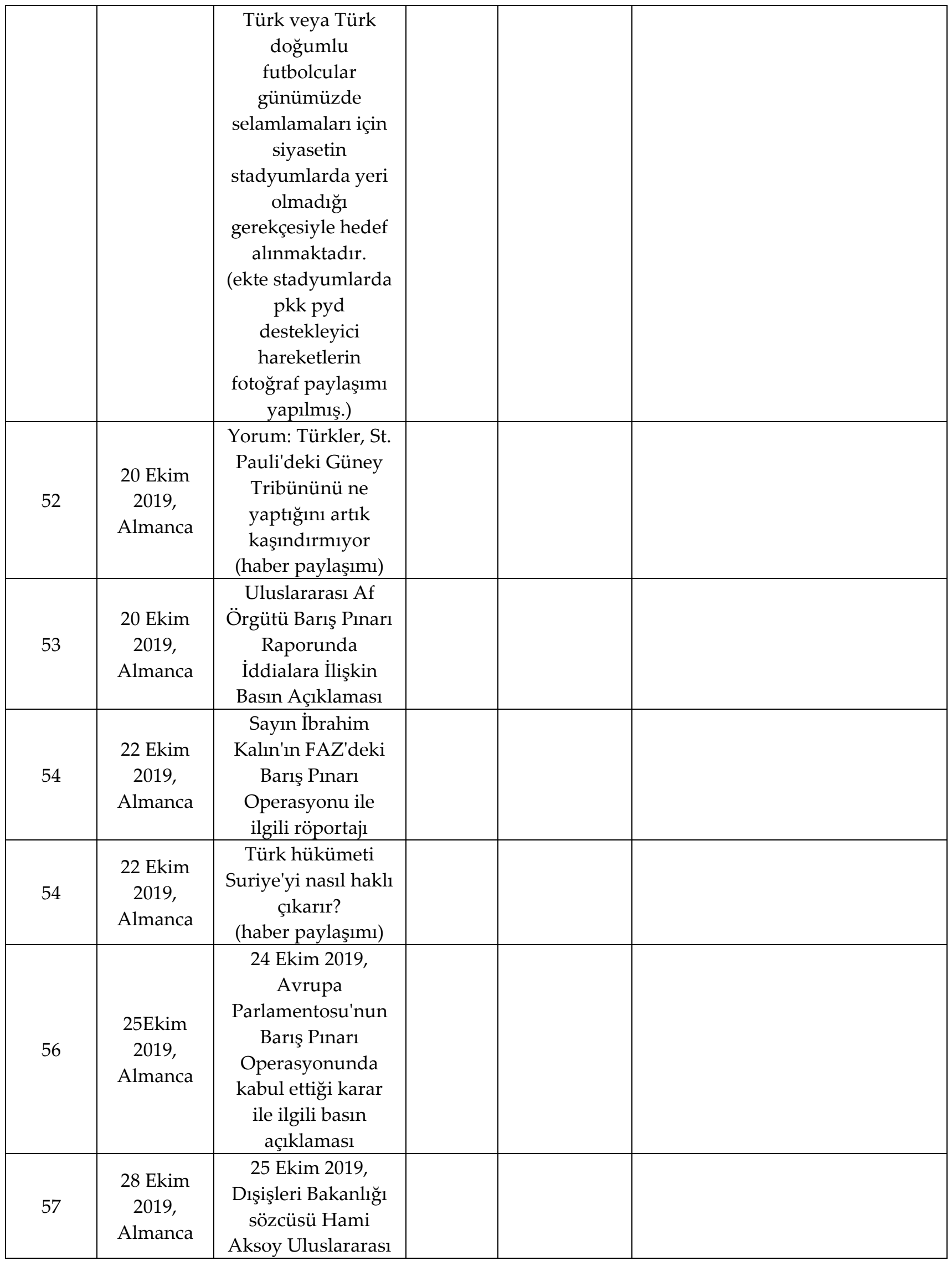


Kamu Diplomasisinde Dijital Dönüşüm: Büyükelçilerin Twitter Üzerinden Gerçekleştirdikleri Dijital Diplomasi Faaliyetlerinin İncelenmesi Mesut İris, Tansu Akdemir

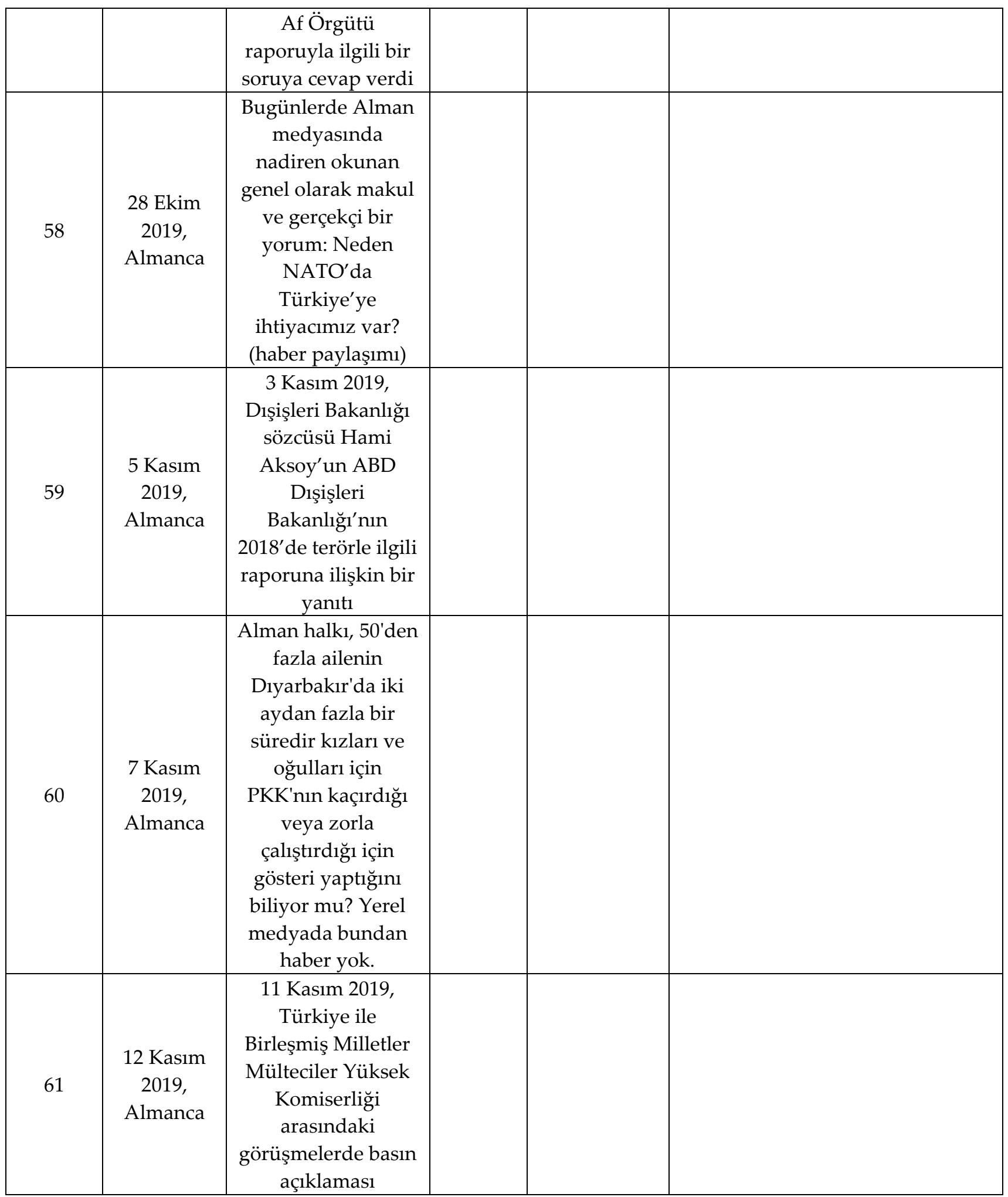

Türkiye Berlin Büyükelçiliği Twitter hesabının harekât ile ilgili paylaşımları yukarıda görüleceği üzere sıralanmıştır. Büyükelçilik Twitter hesabı Aralık 2011 yılından beri faaliyet gösterirken, hesabın yaklaşık 7 bin takipçisi bulunmaktadır. Büyükelçiliğin harekât ile ilgili 
toplam 61 Tweeti, 37 Retweeti vardır. Tweetlerin içeriğine bakıldığı zaman, Harekâtı n nedenlerini, gerekliliğini ve meşruluğunu açıklama odaklı olduğu görülmektedir. Ek olarak Birleşmiş Milletler'e ve Avrupa Birliği'ne yönelik faaliyet paylaşımları da yer almaktadır. Ayrıca Büyükelçilik tarafından, Almanya'da gerçekleşen protestolara, Alman medyasına, Almanya'da Türklere yönelik saldırılara ve asker selamı yaptırımlarına verilen cevaplar yer almaktadir.

Retweetlere bakıldığı zaman, Cumhurbaşkanlığı, Dışişleri Bakanlığı, ilgili bürokratlar ve devlet yetkilileri faaliyetlerinin takip edildiği ve paylaşıldığı anlaşılmaktadır.

Operasyonun nedenleri ve meşruluğu üzerine yapılan paylaşımlarda görsel unsurların kullanılması (adım adım operasyonun nedenlerinin görsel bir şekilde anlatılması), somut haberlerle paylaşımların desteklenmesi, konuyla ilgili uluslararası medyada kaleme alınan yazıların paylaşılması, basın bültenleri paylaşılması ve anlık olarak kamuoyunda gerçekleşen olaylara reaksiyon verikmesi dijital diplomasi faaliyetlerine iyi birer örnek olarak gösterilebilir. Bunun yanısıra Büyükelçilik hesabı takipçi sayısının niceliği ve niteliği de önem arz etmektedir. Nitekim Almanya'da yaşayan Türkler göz önüne alındığında elçiliğin takipçi sayısına yönelik çalışma yapılması gerekmektedir.

\section{SONUÇ}

Kamu diplomasisinin enstrümanlarından biri olan Yumuşak Güç yolu ile askeri veya ekonomik sert yaptırımlar uygulamak yerine işbirliği yaparak elde etmek istediğiniz sonuçlara ulaşabilirsiniz. Yumuşak Güç, başkalarının tercihlerini şekillendirme yeteneğine dayanır (Nye, 2004:5). Bu noktadan hareket ile çatışma ve gerilimlerin çözümünde ülkelerin istedikleri sonuçları alması konusunda uygulayacakları stratejiler gün geçtikçe önem kazanmaktadır. Bu stratejiler arasında dijital diplomasi ülkelerin en çok yatırım yaptığı alanlardan bir tanesi olarak ön plana çıkmaktadır.

Dijital Diplomasi özellikle marka liderler yaratmış, sosyal medya üzerinden anlık olarak liderler arasındaki çatışmalar, anlaşmazlıklar veya çözüm çabaları görülür hale gelmiştir. Liderler ve yetkililer sosyal medya yoluyla birbirlerine ve toplumlara yönelik kamuoyu oluşturucu faaliyetlerde bulunmaktadırlar. Yüz milyon takipçi sayısını aşan marka liderlerin bulunması, etki alanının ne kadar büyük olduğunu göstermektedir. Sosyal medya ile birbirlerine bağlanan ülkeler, Twiplomacy kavramının doğmasına sebep olmuştur. Artık kapalı kapılar ardında diplomatlarca yürütülen diplomasi politikaları yerini milyonlarca takipçinin yer aldığı online platformlara bırakmaktadır.

Çalışmada dijital diplomasi faaliyetlerini yakın tarihli ve uluslararası çapta yankı uyandıran Barış Pınarı Harekâtı üzerinden analiz etmek amaçlanmıştır. Harekât sırasında büyükelçilerin Harekâtı n uluslararası camiadaki haklılığı ve gerekliliğine ilişkin yürüttükleri dijital diplomasi faaliyetleri seçilen sosyal medya örneklemi üzerinden incelenmiştir. 
Uluslararası ortamda günümüzde gelişmiş ülkelerin büyükelçilerinin resmi ve şahsi hesaplarının bulunduğu ve takipçi sayılarının yüksek olduğu görülmüştür. Bu sonuçtan yola çıkarak Türkiye'nin büyükelçilerinin ve büyükelçilik resmi hesaplarının da bulunması önemlidir. Büyükelçilerin şahsi Twitter hesaplarının bulunmaması dijital diplomasi faaliyetleri açısından olumlu bir imaj çizmemektedir. Twitter adresleri bulunan büyükelçilerin ve büyükelçilik resmi hesaplarının da etki alanı açısından takipçi sayılarının arttırılması gerektiği sonucuna varılmıştır. Hesapların bulunması ve takipçi sayılarının arttırılması yapılan paylaşımların gücünü artırırken, etkileşimlerinin de doğru bir şekilde ölçülebilmesine neden olacaktır.

Barış Pınarı Harekâtı özelinde dijital diplomasi faaliyetlerinin gerekliliği hayati bir önemdedir. Nitekim karşıt diplomasi faaliyetlerinin yürütüldüğü ve söz konusu karşıt faaliyetlerin uluslararası platformda toplumları etkileyebilecek nitelikte olduğu görülmektedir. Türkiye açısından devletin üst kademesi, dijital diplomasi faaliyetlerini etkin bir şekilde yürütmüştür. Cumhurbaşkanlığı, İletişim Başkanlığı, Dışiişleri Bakanlığı ve ilgili devlet yetkililerinin şahsi ve resmi twitter adreslerinden görsel kullanımı da olmak üzere, anlık olarak yerel ve yabancı dilde operasyonun haklılığı ve amacı üzerine toplumları aydınlatıcı açıklamalarda bulunulduğu görülmüştür.

Devletin üst kademesinin yanı sıra, yerel düzeyde topluluklara yönelik dijital diplomasi faaliyetleri de aynı oranda önem arz etmektedir. Çalışmanın örneklemine göre değerlendirilen bulgular, büyükelçiliklerin doğru bilgilendirme yapabileceği daha çok bireye ulaşması gerektiğini göstermiştir. Aynı zamanda ortak bir dijital diplomasi stratejisi olarak sadece devletin üst kademesinin gerçekleştirdiği faaliyetlerin paylaşılması gösterilebilir. $\mathrm{Bu}$ faaliyetlere ek olarak yerelde gerçekleşen reaksiyonlara anlık karşılık verilmesi de güçlü bir dijital diplomasi faaliyeti oluşturulmasını sağlayacaktır.

Sadece büyükelçilik nezdinde olmaksızın, devletin ve toplumun direkt veya dolaylı yollardan temsil edildiği her alanda dijital diplomasi faaliyetlerinin desteklenmesi gerekmektedir. Bu anlamda akademik çalışmalar ve araştırmalar yapılmalı, yapılan araştırmalar ilgili kurumlarla paylaşılmalı, kamu - özel işbirlikleri düzenlenmeli, eğitim, seminer, atölye vb. destekleyici çalışmalar yapılmalıdır. Konunun ne denli önemli ve gerekli olduğu, Cumhurbaşkanlığ İletişim Başkanlığı bünyesinde 18 Eylül 2020 tarihinde Resmi Gazete'de yayımlanarak kuruluşu ilan edilen "Stratejik İletişim ve Kriz Yönetimi Dairesi Başkanlığı” ile somutlaşmıştır. 


\section{KAYNAKÇA}

Cassiday, J., \& Johnson, E. (2010). Putin, putiniana and the question of a post-soviet cult of personality. Slavonic and East European Review, 88(4), 681-707. Retrieved from http://www.jstor.org/stable/41061898.

Ekşi, M. (2016). Türk Dıss, Politikasında Diplomasinin Yeni Iletissimsel Boyutları ve Mekanizmaları: Dijital Diplomasi, Uluslararası İlişkilere Disiplinlerarası Bir Yaklaşım: Uluslararası Iletiş̧im Perspektifi, Ed. Burcu Sunar Cankurtaran, İstanbul: Röle Akademik Yayıncılık.

Twitter (2019). https://twitter.com/ihakkimusa internet adresinden 02 Şubat 2020 tarihinde edinilmiştir.

Twitter (2018). https://twitter.com/realdonaldtrump/status/948355557022420992 internet adresinden 05 Ocak 2020 tarihinde edinilmiştir.

Twitter (2019). https://twitter.com/TC_BerlinBE internet adresinden 02 Şubat 2020 tarihinde edinilmiştir.

Twitter (2019). https://twitter.com/turquieparis internet adresinden 02 Şubat 2020 tarihinde edinilmiştir.

Twitter (2019). https://twitter.com/USAmbFrance internet adresinden 02 Şubat 2020 tarihinde edinilmiştir.

İnan, E. (2012). Kamu Diplomasisi ve Halkla İlişkiler Ekseni, A. Özkan, \& T. E. Öztürk (Der.), Kamu Diplomasisi içinde (s. 63-71), İstanbul: TASAM.

Koçak, A. ve Arun, Ö. (2006). İçerik Analizi Çalişmalarinda Örneklem Sorunu, Selçuk İletişim, Cilt 4, Sayı 3.

Kurt, Gözde. (2018). Dijital Diplomasi, Ankara: Akademisyen Kitabevi.

Nye, Joseph S. (2004). Soft Power The Means to Success in World Politics, New York: Public Affairs.

Saka, E., \& Ezgin, S. A. (2016). Dijital Diplomasi: Bir Literatür Incelemesi. In Uluslararası Ilisşkilere Disiplinlerarası Bir Yaklaşım: Uluslararası Iletiş̧im Perspektifi (pp. 55-74). İstanbul: Röle Akademik Yayıncilik.

Su, S., \& Xu, M. (2015). Twitplomacy: Social media as a new platform for development of public diplomacy. International Journal of E-Politics (IJEP), 6(1), 16-29.

Uysal, N., \& Schroeder, J. (2019). Turkey's Twitter public diplomacy: Towards a "new" cult of personality, Public Relations Review, Cilt 45, Say1 5.

Van Dijk, J. (1999). The Network Society, London: Sage Publications.

Yıldırım, B. (2015). İ̧̧erik Çözümlemesi Yönteminin Tarihsel Gelişimi Uygulama Alanları ve Aşamaları, İletişim Araştırmalarında Yöntemler, Ed. Besim Yıldırım, Konya: Literatürk Academia.

Yücel, G. (2016). Dijital Diplomasi, Trt Akademi Dergisi, Cilt 1, Sayı 2. 